\title{
EL PROBLEMA DE LAS SUBSISTENCIAS Y LAS CONDICIONES DE VIDA DE LOS SECTORES POPULARES URBANOS EN EL SALVADOR: CONSUMO, INGRESOS Y ESCASEZ, 1914-1944
}

Luis Rubén González Márquez Universidad de El Salvador luis.gonzalez@ues.edu.sv

Recepción: 17 de mayo de 2017 Aceptación: 3 de junio de 2017 


\section{RESUMEN}

El presente artículo analiza las condiciones de vida de los sectores populares urbanos de El Salvador, a partir del problema de aprovisionamiento de los bienes de consumo básicos durante el período de guerras y entreguerras. A través del contraste entre las estadísticas disponibles y fuentes de la época, se reconstruye el comportamiento de los precios de los alimentos y otros bienes, se contrastan con los ingresos de estos grupos populares citadinos y se describe la dinámica conflictiva de las alzas de precios y la escasez. Aunque fragmentaria, la imagen que resulta permite profundizar otras contradicciones $y$ problemáticas del modelo de desarrollo hacia afuera desde la agroexportación. En concreto, en la precariedad e incertidumbre cotidiana de los heterogéneos sectores que habitaban las ciudades salvadoreñas y en las presiones resultantes sobre el Estado y las clases dominantes, así como sobre los principios de liberalismo económico del proyecto societal vigente.

\section{Palabras Clave}

Condiciones de vida, Espacio urbano, Escasez de alimentos, Sectores populares urbanos, El Salvador

\section{ABSTRACT}

The article analyses the living conditions of urban popular groups, through the case of the problematic acquisition of basic consumer goods during the world's wars and interwar periods. By contrasting available statistics and archive's documents, we present the foodstuffs and other goods prices trends, compare them with these groups incomes and describe the conflictive dynamic of food shortages and high prices. Though fragmentary, the resultant image allows us to deepen our knowledge over the contradictions and problems of the model of agrarian exportation and external development. Specifically, the paper sheds light on everyday material precariousness and uncertainty that define the life of these heterogeneous urban groups and also in the resultant pressures over the Salvadoran State and dominant classes, as well as over the predominant liberal economic principles.

\section{Keywords}

Life conditions, Urban space, Food shortage, Popular urban sectors, El Salvador 


\title{
EL PROBLEMA DE LAS SUBSISTENCIAS Y LAS CONDICIONES DE VIDA DE LOS SECTORES POPULARES URBANOS EN EL SALVADOR: CONSUMO, INGRESOS Y ESCASEZ, 1914-1944
}

\author{
Luis Rubén González Márquez \\ Universidad de El Salvador \\ luis.gonzalez@ues.edu.sv
}

\section{Introducción}

En su estudio Escasez y sobrevivencia: los orígenes ecológicos de la guerra del fútbol, William Durham sostenía que hacia la segunda mitad del siglo XX, la alimentación de los salvadoreños estaba, según los términos de Malthus, en una «dificultad de subsistencia» en lo relativo a la relación entre producción de alimentos y distribución poblacional. Una nueva expansión de la agricultura comercial después de la II Guerra Mundial, que incluyó como consecuencia una profundización de la competencia por la tierra, era el vector crucial que - al sumarse a la explosión demográfica del mismo período- explica una situación extremadamente preocupante: «Tal como lo han manifestado varios autores, El Salvador es el único país en América Latina donde el sorgo (maicillo) se ha convertido en un importante elemento de la dieta humana como lo es también para los animales domésticos». ${ }^{1}$ Como aclaraba el mismo Durham, siguiendo a otros estudios como El Salvador: la tierra y el hombre, de

1 William Durham, Escasez y sobrevivencia en Centroamérica: los orígenes ecológicos de la guerra del fútbol (San Salvador, El Salvador: UCA Editores, 1988), 43. 
David Browning, el de la posguerra era el segundo episodio, dado que en el último tercio XIX había iniciado otra ola previa de expansión de la agricultura comercial de exportación ligada al café. La competencia por recursos y tierras de la creciente agroexportación llevó a la larga, entrado el siglo XX, a una situación de marginalidad a la agricultura de subsistencia, con las consiguientes presiones sobre la alimentación de los habitantes del país. ${ }^{2}$

Desde la publicación de los trabajos de Browning y Durham, la discusión sobre el proceso contradictorio del desarrollo hacia afuera de la economía salvadoreña - por medio de una agricultura capitalista, cuya punta de lanza era el café- ha sido rica en estdudios y polémicas, así como ha dado paso a una ingente literatura. Sin embargo, dentro de estos trabajos las preocupaciones acerca de la alimentación y las condiciones de las subsistencias han caído en un relativo olvido. ${ }^{3}$ Además, ha sido reducida la exploración de las implicaciones de la economía cafetalera para las emergentes ciudades y sus habitantes. Aunque el núcleo del proceso de producción se encontraba en las zonas rurales, desde el último tercio del siglo XIX se consolidaron las poblaciones urbanas — desde las grandes ciudades como San Salvador, Santa

2 William Durham, Escasez y sobrevivencia en Centroamérica; David Browning, El Salvador: la tierra y el hombre (San Salvador: Dirección de Publicaciones e Impresos, 1982).

3 La indagación se ha concentrado en la privatización de tierras, las transformaciones del campesinado, la formación de una burguesía rural, los factores de producción y el Estado frente a estos procesos, cfr. Rafael Menjívar, Acumulación originaria y desarrollo del capitalismo en El Salvador (San Salvador:Abril Uno, 2005); Aldo Lauria-Santiago, Una República agraria: los campesinos en la economía y la política de El Salvador en el siglo XIX (San Salvador: Dirección de Publicaciones e Impresos, 2003); Héctor Lindo-Fuentes, La economía de El Salvador en el siglo XIX (San Salvador: Dirección de Publicaciones e Impresos, 2002); Óscar Campos Lara, «Cafetaleros de Santiago de María : la formación de un poder microregional en la Sierra Tecapa de Usulután, 1874-1917» (Tesis de licenciatura, Universidad Tecnológica de El Salvador, 2007); Erik Ching, «Prólogo: Una República agraria y la historia de la tierra en El Salvador de la Post-independencia», en Una República agraria: los campesinos en la economía y la política de El Salvador en el siglo XIX, de Aldo Lauria-Santiago (San Salvador: Dirección de Publicaciones e Impresos, 2003), 9-27; Dennis Sevillano Payés, «La política rural de mejoramiento social del General Maximiliano Hernández Martínez y sus contradicciones, 1932-1944», Revista de Museología Kóot Año 4, nº 5. (2014): 9-22; Carlos Gregorio López Bernal, «Poder central y poder local en la construcción del Estado en El Salvador, 1840-1890» (Tesis doctoral, Universidad de Costa Rica, 2007); Antonio Acosta Rodríguez, Los orígenes de la burguesía de El Salvador: el control sobre el café y el Estado, 1848-1890 (San Salvador-Sevilla:TEIAA-IEAL-UFG Editores, 2014). 
Ana, Santa Tecla y más tardíamente San Miguel, hasta pequeñas poblaciones intermedias - enclavadas en los valles intervolcánicos de las regiones dedicadas a los cultivos de exportación, precisamente a partir una concentración y una complejización de la circulación del capital agroexportador. Igualmente, las economías urbanas se dedicaban a la producción y distribución de bienes y servicios complementarios e indirectamente dependientes de la agroexportación y de sus actores involucrados: desde la construcción al ocio, pasando por la producción y distribución de manufacturas locales, hasta la comercialización de importaciones europeas, incluyendo las cadenas del mercado alimenticio. ${ }^{4}$

Estos núcleos poblacionales se convirtieron en el sitio de habitación de unos heterogéneos sectores populares urbanos, ${ }^{5}$ que incluían a trabajadores y trabajadoras asalariadas; oficiales, aprendices y dueños de talleres de oficios artesanales; empleados estatales y de comercios; comerciantes formales en pequeño e informales, incluyendo un substrato destacado de vendedoras de mercados. Si bien demográficamente eran un conjunto de población minoritario, a comparación de los habitantes de las zonas rurales, su importancia cualitativa dentro de la imaginación social del período no es menospreciable. ${ }^{6}$ Constituían una alternativa a la proletarización y desposesión en amplias zonas del campo salvadoreño, y por ello eran las primeras expresiones de las larga oleadas de migraciones campo-ciudad — que en la larga duración, a finales del siglo XX, invertirán la proporción de la relación de lugar de habitación de la población salvadoreña, en la actualidad mayoritariamente urbana. En adición, durante estos años los habitantes de las

\footnotetext{
4 Jeffrey Gould y Aldo Lauria-Santiago, 1932: Rebelión en la oscuridad (San Salvador: Ediciones Museo de la Palabra y la Imagen, 2008); Luis Rubén González Márquez, «Sociabilidad y organizaciones artesanales-obreras. La Sociedad de Artesanos El Porvenir de Santa Tecla, 1902-1932" (Tesis de licenciatura en Historia, Universidad de El Salvador, 2012).

5 Sobre los límites y alcances del uso histórico de esta categoría social, cfr. Luis Alberto Romero, «Los sectores populares urbanos como sujetos históricos», Última década n 7. (1997): 9-31.

6 Solo los artesanos-obreros, el grupo más notable en la esfera pública de los sectores populares urbanos, representaba un poco menos del 10 por ciento de la población total hacia 1930, cfr. Luis Rubén González Márquez, «Sociabilidad y organizaciones artesanales-obreras. La Sociedad de Artesanos El Porvenir de Santa Tecla, 1902-1932», 59.
} 
ciudades eran actores centrales del juego político electoral y de la movilización social en una novedosa y ampliada esfera pública. ${ }^{7}$ No obstante, a pesar de su relevancia social y política, los relatos y análisis sobre las condiciones de vida de los sectores populares urbanos en el primer tercio del siglo XX son contradictorios. Por ejemplo, Everett Alan Wilson, en uno de los pocos estudios históricos que aborda esta cuestión, no duda en ubicar a muchos de los miembros de estos grupos dentro de unas crecientes clases medias, con sus relativas comodidades y posibilidades de consumo diversificado, cuya impronta nota en la dinámica de las ciudades, la cultura y la política democrática. En contraste, las propuestas de reforma social del intelectual y ensayista Alberto Masferrer, que planteaban una redistribución económica que brindara las condiciones básicas mínimas - y una reforma moral y cultural que permitiera su uso adecuado- a todos los salvadoreños, decían fundarse en las privaciones materiales de estos grupos. ${ }^{8}$

En el presente artículo abordamos el cruce de estos dos temas, es decir las consecuencias contradictorias del desarrollo hacia afuera sobre la producción de alimentos y bienes básicos, las llamadas subsistencias en el período, y la situación de los habitantes de las ciudades, dependientes de los alcances y falencias de los mercados de bienes básicos y sus ingresos monetarios. En concreto, indagamos cuáles eran las condiciones estructurantes del debatido problema de las subsistencias ${ }^{9}$ y el consumo cotidiano de los sec-

\footnotetext{
7 Luis Rubén González Márquez, «Política popular contenciosa: movilización social y hegemonía en El Salvador, 1919-1932» (Tesis de maestría en Sociología, Facultad Latinoamericana de Ciencias Sociales, Sede Ecuador, 2017); José Mejía Pérez, "Censo del $1^{\circ}$ de mayo de 1930» (San Salvador: Dirección General de Estadística, 1939); Segundo Montes, El Salvador 1988: estructura de clases y comportamiento de las fuerzas sociales (San Salvador: IDHUCA, 1988). 8 Evertt Alan Wilson, La crisis de la integración nacional en El Salvador: 1919-1935 (San Salvador: Dirección de Publicaciones e Impresos, 2004); Alberto Masferrer, El mínimum vital y otras obras de carácter sociológico (Guatemala: Ediciones del Gobierno de Guatemala, 1951); Alberto Masferrer, ¿Qué debemos saber? Cartas a un obrero (San Salvador: Dirección General de Cultura del Ministerio de Educación, 1968).

$9 \mathrm{La}$ aparición recurrente del problema de las subsistencias en las famosas conferencias de Belarmino Suárez y las discusiones en la Sociedad de Artesanos El Porvenir de Santa Tecla son ejemplos palpables de esta preocupación. Belarmino Suárez, Pláticas populares. Lo que no debe ignorar el salvadoreño acerca de la economía nacional (San Salvador: Banco Agrícola Comercial, 1973); Luis Rubén González Márquez, «Sociabilidad y organizaciones artesanales-obreras. La Sociedad de Artesanos El Porvenir de Santa Tecla, 1902-1932».
} 
tores populares urbanos entre 1914-1944. La elección específica del período de guerras y entreguerras obedece a tres criterios: en primer lugar porque se manifestaba la maduración del modelo de desarrollo hacia afuera inaugurado por la expansión de la agricultura comercial decimonónica, con el desarrollo de sus tendencias y contradicciones. En segundo lugar, porque fue un período de crisis de este modelo, tanto por una disputa político-cultural que envolvió a la movilización social, tanto por la discusión pública de los principios de organización económica y el planteamiento de alternativas (incluso radicales) como por las mismas inestabilidades y perturbaciones económicas relacionadas con la Primera Guerra Mundial y la crisis de $1929 .{ }^{10} \mathrm{Y}$, en tercer lugar por la mayor disponibilidad de estadísticas, como nuevo saber-poder asociado al control y gestión de la población desde el aparato central del Estado, ${ }^{11}$ así como de noticias, descripciones e incluso estudios nacionales y regionales para contrastarlas, si bien no deja de pesar la fragmentaridad de los mismos. ${ }^{12}$ Como han destacado las recientes propuestas de historia global en torno a la Gran Guerra y su respectiva posguerra, este momento constituye coyuntura de transformaciones económicas de configuración del mundo contemporáneo, dentro del cual las condiciones de vida y sus consecuencias fueron una trama importante de movilizaciones a gran escala, revoluciones y

10 Víctor Bulmer-Thomas, La economía política de Centroamérica desde 1920 (San José: Banco Centroamericano de Integración económica-EDUCA, 1989); Jeffrrey Gould y Aldo LauriaSantiago, 1932: rebelión en la oscuridad.

11 Las transformaciones económicas de El Salvador, desde el último cuarto del siglo XIX con motivo de su nueva integración al mercado internacional, fueron paralelas - y con complejas relaciones de condicionamiento mutuo- al crecimiento de las estructuras estatales, que incluían un ensanchamiento de sus funciones y de su efectividad. De manera concomitante, ambos procesos se entrelazaban en la configuración de una nueva biopolítica y sus saberes asociados con la administración jurídico-política, el conocimiento del territorio y de la población, para facilitar su gestión adecuada según los fines de la organización de la reproducción material y el nuevo ejercicio de la soberanía. Entre esos saberes se contaba la estadística que, no sin limitaciones materiales y de precisión de la información, atestiguó un esfuerzo creciente de registro e indagación, tanto por intelectuales como Pedro Fonseca o Hermógenes Alvarado, como por una nueva instancia administrativa dedicada a tal fin: la Dirección General de Estadística. Cfr. Michel Foucault, Defender la sociedad: curso en el Collège de France (1975-1976) (Buenos Aires: Fondo de Cultura Económica, 2000).

12 Como se podrá verificar a lo largo del artículo, se ha seguido con detalle el caso regional al Departamento de La Libertad. 
la crítica del liberalismo económico. ${ }^{13}$ Con sus especificidades, El Salvador y Centroamérica formaron parte de este proceso más amplio. ${ }^{14}$

Con este propósito, la aproximación a las subsistencias y las condiciones de vida de los sectores populares urbanos salvadoreños inicia con un rastreo de las tendencias de los precios de los granos básicos, los cuales constituían el centro del debate sobre los encarecimientos de las subsistencias. Después se aborda el consumo a través del contraste entre los precios de los alimentos y otros bienes básicos en los mercados locales con los ingresos de los sectores populares urbanos, en algunos casos y años que fue posible reconstruir.Y, al final, se analizan con detalle los períodos de escasez y alzas agudas de precios, en sus modalidades, su frecuencia coyuntural, dinámica específica y las variadas respuestas del Estado y otros actores. Como veremos, las presiones del modelo de agroexportación sobre la agricultura de subsistencia y los mercados de bienes básicos, junto a las restricciones de ingreso y la inexistencia de mecanismos de seguridad social, se expresaron en una enorme inestabilidad en las posibilidades de consumo de los sectores populares urbanos. Esta alta incertidumbre (más que una mera incapacidad adquisitiva) era un preocupante factor de precariedad de estos sectores, con consecuencias derivadas en su relación con el Estado, las clases dominantes y en la configuración de sus subjetividades.

\section{Precios de los granos básicos: algunas tendencias}

Gracias a la conjunción de la producción de saber estadístico con la preocupación pública que generaban las manifestaciones más patentes del problema

\footnotetext{
13 Lynne Taylor, «Food Riots Revisited», Journal of Social History Vol. 30, nº 2 (1996):483-496; Derek Aldcroft, «Las consecuencias económicas de la guerra y de la paz, 1919-1929», en Europa en crisis, 1919-1939, ed. Mercedes Cabrera, Santos Juliá, y Pablo Martín Aceña (Madrid: Editorial Pablo Iglesias, 1991),1-24; Charles Tilly, "Capítulo 6: Rusia y sus vecinos», en Las revoluciones europeas, 1492-1992 (Barcelona: Crítica, 2000), 268-75; cfr. Universidad Libre de Berlín, «1914-1918-online: International Encyclopedia of the First World War», F. Enciclopedia en línea (2011), disponible en: www.1914-1918-online.net

14 En Guatemala cfr. David McCreery, «Debt servitude in rural Guatemala, 1876-1936», Hispanic american historical review Vol. 63, n 4, (1984): 735-759.
} 
de las subsistencias, de las que, entre otras razones, surgió la necesidad de generar un conocimiento certero e inmediato, es posible encontrar relevantes y sostenidas series de indicadores sobre aprovisionamiento alimenticio en este período. Probablemente los mejores de estos indicadores sean los precios de los granos básicos que se consumían en el país durante estos años: maíz, frijol y arroz. Por un lado, porque hubo un registro constante de su variación periódica a nivel nacional y en cada departamento del país, el cual desde 1914 se convirtió en un registro sistemático publicado en los Anuarios estadísticos de la Dirección General de Estadística.Y, por otro lado, porque si bien no agotan completamente las subsistencias ni las dificultades que enfrentaban los sectores populares urbanos del período para aprovisionarse de ellas- al constituir estos granos la base alimenticia de la población después de "las revoluciones alimentarias» siglo XVIII en el sistema capitalista global, ${ }^{15}$ señalan un aspecto fundamental de la reproducción material en sociedades periféricas como El Salvador principios del siglo XX.

\section{Cuadro 1:}

Períodos de cosechas principales de los granos básicos en El Salvador, 1934

\begin{tabular}{|c|l|}
\hline Grano & Períodos de cosechas \\
\hline Maíz & $\begin{array}{l}\text { De invierno: Septiembre-noviembre } \\
\text { De verano: noviembre-febrero }\end{array}$ \\
\hline Frijol & $\begin{array}{l}\text { Invierno: agosto-septiembre } \\
\text { Verano: diciembre }\end{array}$ \\
\hline Arroz & Octubre-noviembre \\
\hline
\end{tabular}

Fuente: Dirección General de Estadística, Anuario estadístico de 1934

(San Salvador: Imprenta Rafael Reyes, 1935), 21 y 22.

Ahora bien, antes de entrar de lleno a un análisis de los precios de los granos básicos, es necesario hacer algunas consideraciones previas. Cualquier análisis de variación debe tomar en cuenta que en cada año existía una

15 Fernand Braudel, Civilización material, economía y capitalismo. Siglos XV-XVIII. Tomo I: las estructuras de lo cotidiano: lo posible y lo imposible (Madrid: Alianza, 1984), 75-79 y 130-139. 
calendarización de escasez y aumento de precios definida por el régimen de cosechas vigente en la época (ver Cuadro 1). Algunas descripciones indican que a medida que se alejaban los meses de cosecha de determinado grano, aumentaba la probabilidad de precios altos y el peligro de la escasez. ${ }^{16}$ No es casualidad que al tener una sola cosecha y un mayor tiempo para la especulación de precios, el precio del arroz haya presentado una mayor volatilidad. También se debe tomar en cuenta que el proceso directo de registro de precios en cada mercado era efectuado por funcionarios municipales y a veces por delegados de los gobernadores, quienes se enfocaban en el movimiento del mercado mayorista. Los precios registrados estaban debajo del de compra que efectuaban los consumidores.Y la exactitud de los mismos podía verse afectada por desconocimiento de los procedimientos estadísticos o por connivencias entre especuladores y funcionarios del registro, si bien estos dos problemas se compensaban con la preocupación pública y estatal en torno al problema de las subsistencias, que impulsaba a las altas esferas a obtener datos fehacientes y fiables.

Con estas consideraciones en cuenta, es posible analizar el comportamiento del precio medio nacional anual de los granos básicos entre 1914 y 1942, como lo expresan los gráficos 1,2 y 3.

\section{Gráfico 1: Precios de quintal de maíz en El Salvador (1914-1942)}

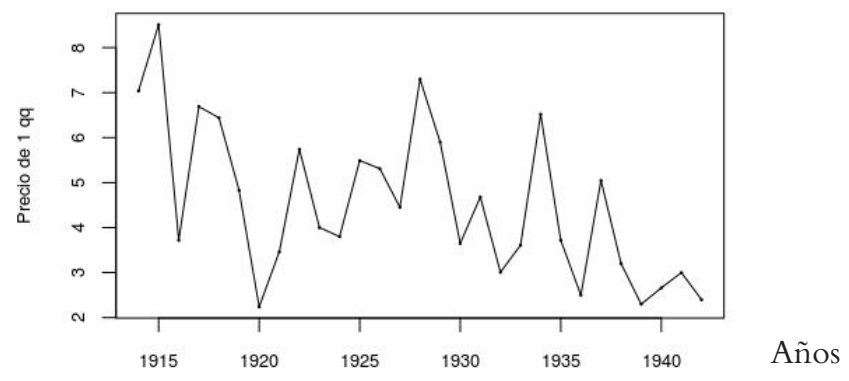

Fuente: Dirección General de Estadística, Anuarios estadísticos, 1937-1942

(San Salvador: Imprenta Rafael Reyes, 1938-1943)

16 Por eso en Guatemala, McCreery encontró que los contratistas (habilitadores) de trabajadores para las fincas reclutaban mediante el endeudamiento a los indígenas de «los pueblos de las tierras altas principalmente en julio-agosto, cuando el maíz era escaso y dispendioso". David McCreery, «Debt servitude in rural Guatemala, 1876-1936», 744. 
Gráfico 2: Precios de quintal de frijoles en El Salvador (1914-1942)

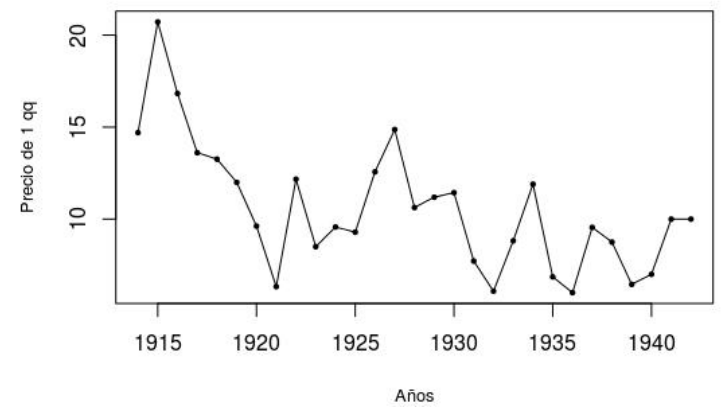

Fuente: Dirección General de Estadística, Anuarios estadísticos, 1937-1942

(San Salvador: Imprenta Rafael Reyes, 1938-1943)

\section{Gráfico 3: Precios de quintal de arroz en El Salvador (1914-1942)}

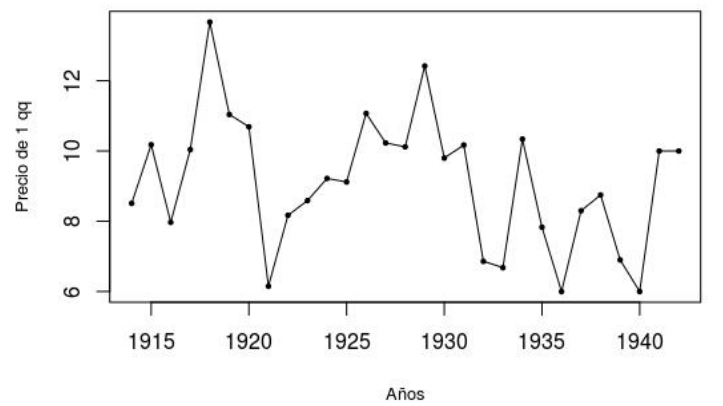

Fuente: Dirección General de Estadística, Anuarios estadísticos, 1937-1942

(San Salvador: Imprenta Rafael Reyes, 1938-1943)

El comportamiento de los precios básicamente seguía dos tendencias, según la temporalidad que consideremos. En la larga duración notamos una leve pero sostenida disminución, especialmente en los frijoles y el maíz: el primero no superó la barrera de los 15 colones el quintal después de 19201921 y, desde 1935, la de 10 colones. Mientras, el maíz nunca alcanzó los 8.51 pesos de 1915 y, desde 1937, no sobrepasó la barrera de los 5 colones el quintal. Con el arroz la reducción fue menos marcada. Esta disminución está profundamente condicionada por el umbral de 1920-1921, considerando la 
inestabilidad monetaria que definió a todas las repúblicas de Centroamérica antes de la transición al patrón oro, dado que, según Víctor Bulmer-Thomas, existía una tendencia a la apreciación del tipo de cambio favorable a la exportación de café, pero lesiva a los consumidores de bajos recursos e incluso a los importadores. ${ }^{17}$ En la coyuntura de 1914-1920, esta condición estructural se vio agravada por las perturbaciones comerciales internacionales y locales vinculadas a la Gran Guerra y el contexto de la inmediata posguerra, así como por la «miseria terrible», como la describió un testigo, que sucedió al terremoto de $1917 .{ }^{18}$ En efecto, fue en ese período que se alcanzó el precio máximo — dentro de la serie que hemos construido- de los tres granos básicos: 13.67 pesos en 1918 para el arroz, 20.7 en 1915 para los frijoles y los referidos 8.51 del maíz en 1920 (en los tres casos, desviaciones extremas de la media, respectivamente $(z=2.40,2.95$ y 2.34). Y, casi inmediatamente después de esta alza, algunos de los precios más bajos del período: 2.24 el quintal de maíz en $1920(z=-1.34), 6.33$ el de frijoles $(z=-1.23)$ y 6.15 el de arroz en $1921(z=-1.58)$.

A pesar de los efectos positivos de la estabilidad monetaria en el mercado de los granos básicos ${ }^{19}$, e incluso de que hubiera marcados descensos de precios durante o después de su adopción, no se debe olvidar que las reformas de 1920-1921 —que incluían establecer el colón como moneda, en paridad con el peso, y sacar de circulación la plata— también acentuaron las desigualdades sociales y motivaron conflictos por los daños inmediatos que ocasionaron para la economía de los sectores populares urbanos, así

17 Bulmer-Thomas, La economía política de Centroamérica desde 1920, 13 y 14.

18 Dereck Aldcroft, «Las consecuencias económicas de la guerra y de la paz, 1919-1929», 14-16; entrevista a Miguel Mármol por Ernesto Isunza Vera, citada en Ernesto Isunza Vera, "Cosmovisión de la vieja guardia. Organizaciones y cultura comunistas centroamericanas, 1922-1934» (Tesis de licenciatura, Universidad Veracruzana, 1993), 62.

19 Dereck Aldcroft, «Las consecuencias económicas de la guerra y de la paz, 1919-1929», 14-16; entrevista a Miguel Mármol por Ernesto Isunza Vera, citada en Ernesto Isunza Vera, «Cosmovisión de la vieja guardia. Organizaciones y cultura comunistas centroamericanas, 1922-1934» (Tesis de licenciatura, Universidad Veracruzana, 1993), 32. 
como por resultar favorables a financistas y especuladores ${ }^{20}$. Asimismo, se debe considerar que esta reducción fue también efecto de determinadas acciones estatales de contención de alzas de precios de los granos básicos - las cuales analizaremos más adelante- - y no sólo de las reformas monetarias.

La segunda tendencia del comportamiento de precios se manifestaba en el corto plazo y constituía un rasgo estructural del mercado de granos básicos lesivo para la reproducción material de los sectores populares urbanos: la marcada inestabilidad coyuntural e interanual de los precios. La media del precio del quintal, sin desviaciones extremas, correspondió a 4.52 pesos el maíz, a 10.2 pesos los frijoles y 8.97 el arroz; mientras la desviación estándar de cada uno fue de 1.7, 2.89 y de 1.89 pesos. Como se puede notar, la mayor variabilidad correspondía a los frijoles. ${ }^{21}$ Más aun, esa inestabilidad de los precios se expresaba de mes a mes e incluso por semana, más allá de la estacionalidad de precios según las cosechas, descrita en el Cuadro 1. Por ejemplo, un mes después de la cosecha de verano del maíz, en marzo y abril de 1902, el Diario Oficial reportó los precios corrientes de algunas semanas: en el departamento de La Libertad, del 16 al 22 de marzo, el precio de la fanega de maíz fue de 12 pesos (aproximadamente 18.46 pesos el quintal) y el de la fanega de frijoles negros, de 30 pesos (40 pesos el quintal); mientras del 31 de marzo al 5 de abril, el precio de la fanega de maíz había subido a 15 pesos (23.08 pesos el quintal) y la de frijoles negros a 36 pesos (48 pesos el quintal $)^{22}$.

\footnotetext{
20 Héctor Lindo-Fuentes, «La United Fruit Company y el empréstito de 1922 en El Salvador», F. Boletín AFEHC n 64 (4 de marzo de 2015), disponible en: http://afehc-historiacentroamericana. org/index.php?action=fi_aff\&id=393; Luis Rubén González Márquez, «Política popular contenciosa: movilización social y hegemonía en El Salvador, 1919-1932». 21 Por ejemplo, los frijoles pasaron de 8.5 pesos (el quintal) en 1923, a 9.57 en 1924; luego bajaron a 9.29 en 1925 y alcanzaron los 12.57 en 1926 (Gráfico 2).

22 Diario Oficial, tomo 52, núm. 76, $1^{\circ}$ de abril de 1902, 602; Diario Oficial, tomo 52, núm. 83, 9 de abril de 1902, 681. Cabe destacar que este tipo de variaciones eran regulares, según se nota en las páginas de esta fuente. No llegaba aún a reportarse como los fenómenos de encarecimiento y escaseces agudas que analizaremos más adelante. Los cálculos de peso de la fanega y su conversión a quintal se han fundado, a falta de otros formulados para El Salvador del período, en los cálculos del antropólogo David Frye (1fanega de maíz equivalente a 65 kg y 1 de frijoles a $75 \mathrm{~kg}$, para México) y, en todo caso, son una mera aproximación, pues la fanega es una medida de capacidad y el quintal de peso. David Frye, «Metrología», University of Michigan, F. David Frye. Writer...Translator (2012), disponible en: http://www-personal. umich.edu/ dfrye/fanega.htm.
} 
Una comparación de estas tendencias nacionales con los datos del departamento de La Libertad permite elaborar una aproximación inicial a las diferencias regionales de acuerdo al peso de factores diversos como los transportes, la población, la diferente capacidad de aprovisionamiento de subsistencias por región, las redes comerciales, el ingreso o la competencia que presentaba la agricultura de exportación. En el caso concreto de La Libertad, era una región profundamente vinculada a la agricultura de exportación y las redes comerciales y productivas de la capital del país: incluía una zona cafetalera enorme alrededor del volcán de San Salvador, aunque también otras zonas adyacentes de agricultura de subsistencia y una región costera menos poblada; su mercado interno estaba profundamente vinculado al de la capital; contaba además con un puerto propio con alta movilidad de exportaciones e importaciones, y en general experimentaba un importante crecimiento urbano y demográfico ${ }^{23}$.

Los gráficos 4, 5 y 6 especifican los precios de los granos básicos en el departamento de La Libertad en el período 1928-1939, la serie más larga de datos departamentales específicos que presentan los Anuarios estadísticos; mientras el Cuadro 2, una comparación de la media y la variación nacional y departamental para estos 12 años. El departamento de La Libertad presentaba unos precios ligeramente menores en el arroz y los frijoles y levemente mayores del maíz. Ahora bien, con respecto a la variación, aunque era poco significativa la diferencia entre el promedio nacional y departamental con respecto a los frijoles y el maíz, con respecto al arroz era marcada: si el indicador nacional llegaba a una desviación de 1.93 pesos, en este departamento alcanzaba los 2.71. Probablemente, esta mayor variabilidad se relacione con la ausencia de zonas productoras de arroz, dentro o en las proximidades de La Libertad, y por lo tanto, con un mayor grado de dependencia en las distintas cadenas comerciales internas e incluso internacionales para aprovi-

23 Herberth Morales, «Historia local de Jayaque» (Tesis de licenciatura, Universidad de El Salvador, 2013); «Dinámicas poblacionales de Santa Tecla: población en Santa Tecla, 18541882 (inédito)" (s.e., s.f.); Geraldina Portillo, La tenencia de la tierra en El Salvador: La Libertad, 1897-1901, Santa Ana, 1882-1884, 1897-1898 (San Salvador: Instituto de Estudios Históricos, Arqueológicos y Antropológicos de la Universidad de El Salvador, 2006). 
sionarse de este producto. Con todo, el comportamiento de los precios de los granos básicos en La Libertad seguía en la mayoría de años el patrón al alza o a la baja de los precios nacionales. Por ejemplo, el máximo precio del frijol a nivel nacional, entre 1928-1942, se alcanzó en 1934 y fue de 11.9 colones el quintal; en La Libertad este precio máximo fue en el mismo año con 11.46 colones.

\section{Gráfico 4: Precios de quintal de maíz en el departamento de La} Libertad, 1928-1939 (en colones)

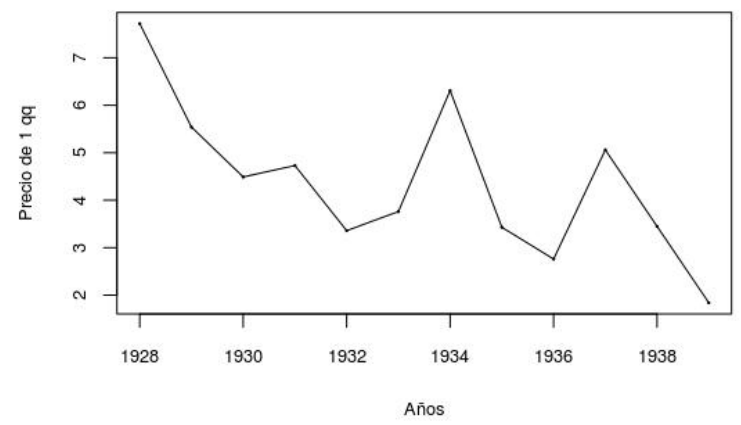

Fuente: Dirección General de Estadística, Anuarios estadísticos, 1928-1939, (San Salvador: Imprenta Rafael Reyes, 1928-1939)

Gráfico 5: Precios de quintal de frijoles en el departamento de La Libertad, 1928-1939 (en colones)

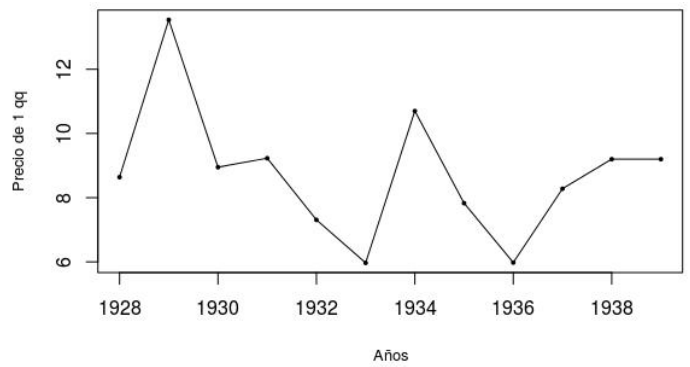

Fuente: Dirección General de Estadística, Anuarios estadísticos, 1928-1939 (San Salvador: Imprenta Rafael Reyes, 1928-1939) 
Gráfico 6: Precios de quintal de arroz en el departamento de La Libertad, 1928-1939 (en colones)

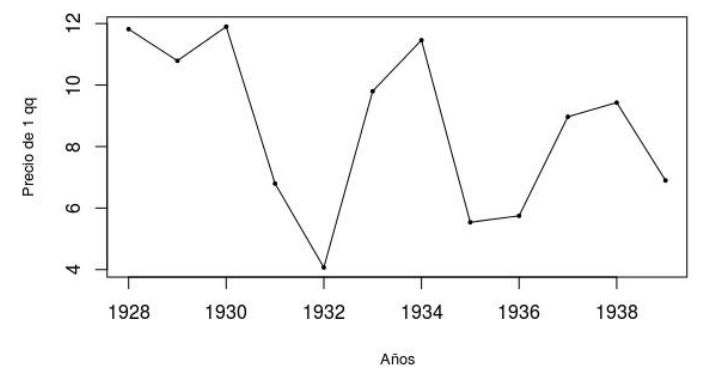

Fuente: Dirección General de Estadística, Anuarios estadísticos, 1928-1939

(San Salvador: Imprenta Rafael Reyes, 1928-1939)

Cuadro 2: Comparación de precios y variación del quintal de granos básicos a nivel nacional y del departamento de La Libertad 1928-1939 (en colones)

\begin{tabular}{|c|c|c|c|l|}
\hline Grano & $\begin{array}{c}\text { Media } \\
\text { nacional }\end{array}$ & $\begin{array}{c}\text { Media } \\
\text { de La } \\
\text { Libertad }\end{array}$ & sd nacional & $\begin{array}{l}\text { sd de La } \\
\text { Libertad }\end{array}$ \\
\hline Maíz & 4.29 & 4.34 & 1.61 & 1.63 \\
\hline Frijol & 8.78 & 8.74 & 2.17 & 2.04 \\
\hline Arroz & 8.68 & 8.60 & 1.93 & 2.71 \\
\hline
\end{tabular}

Fuente: Dirección General de Estadística, Anuarios estadísticos, 1928-1942, (San Salvador: Imprenta Rafael Reyes, 1928-1942)

En suma, entre 1914 y 1944 se registró una relativa disminución de precios de los granos básicos en la larga duración, pero bajo una marcada inestabilidad coyuntural de precios que se replicaba, con algunas diferencias relativas, a nivel regional. La anterior situación remite a la hipótesis de Víctor Bulmer-Thomas, de la existencia de una competencia de recursos como préstamos, apoyo estatal y principalmente tierras y mano de obra, entre la 
agricultura de subsistencia y agricultura de exportación. Bulmer Thomas planteaba que aquél fue uno de los efectos más perversos en toda Centroamérica de la apuesta por el crecimiento hacia afuera mediante la producción y exportación de bienes primarios ${ }^{24}$. La situación salvadoreña es comparable a la de Guatemala, donde David McCreery exploró cómo el crecimiento de la agricultura de exportación y la reorganización del mercado de trabajo desde el Estado conllevaron a un «desequilibrio de la formación socioeconómica de las tierras altas»: sobrepoblación, falta de brazos para la agricultura de subsistencia en períodos críticos, monetarización de la economía comunitaria, "creación de nuevas necesidades que sólo podían ser satisfechas con el dinero de las fincas» y un comportamiento de los precios de los granos básicos con enormes similitudes al panorama descrito en El Salvador, aunque sin la regionalización guatemalteca con su altiplano, y más bien con una distribución accidentada de los resguardos interno-coloniales de agricultura de subsistencia funcional al capitalismo agrario ${ }^{25}$.

Los efectos del comportamiento de los precios de los granos básicos en el mercado interno no pueden definirse como lesivos en términos absolutos, dada su tendencia larga a una reducción paulatina desde por lo menos 1919-1921, favorable a los compradores (aunque no necesariamente para los pequeños productores rurales) y coherente con la relativa diversificación y aumento del consumo urbano, como se vuelve patente en los hallazgos de las investigaciones sobre la ciudades y los sectores medios salvadoreña $\}$ os del período ${ }^{26}$. Sin embargo, ese reducción relativa de precios y el aumento de la

24 Bulmer-Thomas, La economía política de Centroamérica desde 1920, 48 y 58.

25 McCreery describe que la de Guatemala era «una economía en la cual los costos de los alimentos fluctuaban típicamente durante el año y en diferentes áreas del país», cuyos consumidores se enfrentaban a "cambios impredecibles en el mercado año con año", pues eran «dependientes del maíz de pequeños productores infracapitalizados y con cada vez menor capacidad de trabajo». Aunque las similitudes son evidentes con el caso salvadoreño, hacen falta estudios de historia y sociología comparativa que aborden las similitudes y diferencias de la agroexportación y la estructuración social de estos dos países centroamericanos. David McCreery, Debt servitude in rural Guatemala, 1876-1936, 750-59.

26 Evertt Alan Wilson, La crisis de la integración nacional en El Salvador:1919-1935; Víctor Hugo Acuña Ortega, «The Formation of the Urban Middle Sectors in El Salvador, 1911-1944», en Landscape of Struggle: Politics, Society and Community in El Salvador, ed. Leigh Binford y Aldo Lauria-Santiago (Pittsburgh: University of Pittsburgh Press, 2004), 39-49; Carlos Gregorio López Bernal, Tradiciones inventadas y discursos nacionalistas: El imaginario nacional de la época liberal en El Salvador, 1876-1932 (San Salvador: Editorial Universitaria, 2007). 
capacidad de consumo era insuficiente para generalizar el optimismo de interpretaciones como la de Everett Alan Wilson, que apuntan a la emergencia de unas fortalecidas clases medias. El «desequilibrio de la formación socioeconómica» salvadoreña se expresaba cotidianamente durante el período entreguerras en la inestabilidad del precio de los granos básicos. Esta volatilidad era un factor que ubicaba en primer plano las vulnerabilidades en las condiciones de vida de los sectores populares urbanos y, en definitiva, tensaba los presupuestos de la economía liberal ¿Qué implicaciones concretas tuvieron estas tendencias para la reproducción material de aquellos grupos desligados de la agricultura, dependientes de ingresos salariales y la compraventa de los productos básicos en el mercado interno?

\section{Consumo e ingresos frente a los precios corrientes de las subsistencias, o los dilemas de la sobrevivencia cotidiana}

Las tendencias anteriormente expuestas de los precios de los granos básicos eran preocupantes para cualquiera no vinculado directamente a la agricultura de subsistencia, e indican de por sí la precariedad a la que se enfrentaban los sectores populares urbanos de El Salvador. Se puede conocer en mayor detalle la evolución del problema de las subsistencias, si logramos hacer un contraste de los precios corrientes de los bienes básicos con el ingreso de los mencionados sectores. Con ello, es posible considerar otros productos básicos además de los granos, el precio que tenían al menudeo después de pasar por intermediarios, y compararlos con una aproximación a la capacidad adquisitiva de los citadinos pobres. A diferencia de los precios de los granos, la fragmentación de las fuentes ha imposibilitado reconstruir series completas de los precios corrientes y del ingreso, por lo cual se analizado este problema siguiendo casos locales o específicos contrastados con algunos lustros o períodos medianos de fuentes seriadas.

El indicador más elusivo para hacer un análisis más completo de los precios y capacidad de compra fue el volumen medio del consumo específico de los bienes básicos de los sectores populares urbanos. Obviamente, 
cuánto se consumía de uno u otro bien variaba precisamente por el precio corriente de los bienes y el ingreso, aunque también por culturas del consumo vigentes. Aunque fuera consecuencia del precio y los salarios, resultaría fundamental tener datos de las cantidades de consumo específicas para introducirlo en un análisis seriado de la variación del consumo, empero, lamentablemente, fue pasado por alto por los encargados de las estadísticas y por la mayor parte de estudiosos de la época. Una excepción resultó La demografía salvadoreña, de Pedro Fonseca — tal vez el intelectual positivista que más trabajó por la recopilación de estadísticas a principios del siglo XX- que contiene algunas observaciones del consumo promedio de granos básicos de los campesinos; es decir, de los pequeños propietarios, colonos y jornaleros rurales. Fonseca señala que, según sus cálculos, al día los campesinos consumían 0.56 libras diarias de maíz y 0.59 libras de frijol, y observaba que era un consumo precario para sus necesidades vitale ${ }^{27}$. Se debe tomar en cuenta que es altamente probable que el nivel de consumo de estos dos granos fuera más alto para los habitantes urbanos, por su mayor capacidad adquisitva. A esto se agrega que ese consumo se pudo ver afectado por la extrema variación de precios del contexto en que se recopilaron, precisamente la coyuntura de 1919-1921. Con todo, esta observación de Fonseca es la más aproximada disponible sobre el consumo de maíz y frijoles, y por esta razón constituirá un punto de referencia para plantear algunas inferencias del consumo según precio de granos y capacidad adquisitiva.

Las condiciones heredadas del siglo XIX no eran favorables en absoluto en lo referente al consumo de los sectores populares urbanos. En 1888, Rafael Reyes expuso algunos datos que describen el preocupante panorama del consumo y los salarios de los sectores populares urbanos. Por un lado, Reyes indicaba las limitaciones salariales: por ejemplo, el salario de los operarios de sastrería, albañilería y carpintería mejor pagados de sus oficios era de 1 peso diario, 24 pesos en un mes de seis jornadas laborales

27 «La ración alimenticia diaria de los campesinos salvadoreños es de 276 gramos de maíz y 289 de frijol, que reunidos forman un equivalente termodinámico de 1975 calorías. Un peón que trabaja ocho horas al día en país tropical necesita de 2750 a 2900 calorías, según el peso». Pedro Fonseca, Demografía salvadoreña (San Salvador: Imprenta Rafael Reyes, s.f.), 54. 
por semana y 228 colones anuales $^{28}$. Por otro lado, el mismo autor indicaba el precio corriente de algunos artículos básicos. De aquéllos de menor valor en su lista, se encontraban: una libra de carne a $0.12^{1} \frac{1}{2}$ pesos; una fanega de frijoles a 15 ; una libra de cacao salvadoreño a $0.37 \frac{1}{2}$; una fanega de maíz a 2 ; un quintal de café a 18 ; una fanega de arroz a $\$ 1.50$; una libra de sal marina a 0.06; un galón de "Kerosine» (sic) a 0.80; una arroba de azúcar a 1.25; 1 arroba de quesos de leche a 5 pesos, y una botella de leche a $0.12 \frac{1}{2}$ pesos. Al contrastar salarios e ingresos, notamos que los albañiles, carpinteros y sastres mejor pagados no tenían la capacidad adquisitiva de comprar el anterior listado de productos con su salario mensual, y apenas podrían haber cubierto el 54.3 por ciento. Sólo en el maíz y frijoles que ellos consumían diariamente, sin añadir dependientes, considerando los datos de Fonseca sobre consumo y los de Reyes sobre precios corrientes, estos artesanos debían gastar respectivamente 0.03 y 0.30 pesos, o 33 por ciento de su salario diario en esos alimentos.

Los hallazgos para el período de 1914-1944 permiten profundizar en las continuidades y diferencias con el panorama descrito con Reyes, y conocer otras dinámicas asociadas gracias la mayor disponibilidad de fuentes. En efecto, aparte de la incapacidad de pago de bienes básicos, el consumo de los sectores populares urbanos se veía atrapado entre unos limitados ingresos con una tendencia a la estabilidad y la variabilidad del precio de las subsistencias. El comportamiento constante de los ingresos queda ilustrado por los resultados del caso de los salarios de los carteros de Santa Tecla, en los presupuestos y las leyes de salario disponibles en las cuatro primeras décadas del siglo XX. Los carteros tecleños son un caso significativo por su pertenencia a los sectores populares urbanos como trabajadores asalariados, el registro sistemático de sus salarios por el Estado, el interés en la comunicación postal,

28 Rafael Reyes, Apuntamientos estadísticos sobre la República de El Salvador de 1888 (San Salvador: Imprenta Nacional, 1888), 39. El salario menor de cualquier trabajador urbano, registrado por Reyes, era 4 reales o medio peso; los mejor pagados eran los trabajadores de imprenta, pues su salario máximo era de 12 reales o un peso y medio. Las observaciones de Reyes son consecuentes con los hallazgos de Acosta para el siglo XIX. Antonio Acosta Rodríguez, Los orígenes de la burguesía de El Salvador, 251. 
la posición intermedia del salario de estos carteros como carteros de segunda clase - los de primera eran los de San Salvador y Santa Ana, mientras los de tercera eran de los pueblos del interior-y por su ubicación en la cabecera de La Libertad, un caso para el que hemos encontrado una cantidad importante de datos sobre precios. El resultado fue una inmovilidad casi absoluta en los salarios de estos carteros: en todos estos años equivalió anualmente a 480 pesos (o colones, después del cambio monetario de 1920-1921) en el período de 1909-193129. Las observaciones de otros trabajadores urbanos en los presupuestos y leyes de salario nacionales indican esta tendencia a la estabilidad, como le sucedía a los jefes de taller de zapatería y albañilería de la Penitenciaría Central el cual, en la década de los 20, se quedó fijo en los 720 colones anuales ${ }^{30}$.

Obviamente, esta inmovilidad absoluta está exagerada en los datos anteriores por provenir de trabajadores cuyo pago estaba determinado anualmente por los presupuestos estatales ${ }^{31}$. En importantes grupos de los sectores populares urbanos que no dependían del Estado, como los artesanos y las vendedoras de los mercados, la condición de constante de los ingresos era más bien relativa y dependía de los vaivenes del mercado, así como de la tradición. Incluso en períodos extraordinarios hubo momentos de bonanza, pero aun en estos casos se manifiesta la tendencia a la continuidad

29 Diario Oficial, Tomo 68, núm. 130, 6 de junio de 1910, 145; Diario Oficial, Tomo 72, núm. 136, 12 de junio de 1912, 1275; Archivo General de la Nación, Fondo Ministerio de Gobernación-del Interior, Ley de Presupuesto de 1916-1917; Diario Oficial, Tomo 96, núm. 147, 28 de junio de 1926, 1380; Archivo General de la Nación, Fondo Ministerio de Gobernación-del Interior, Ley de Presupuesto de 1927-1928; Archivo General de la Nación, Fondo Ministerio de Gobernación-del Interior, Ley de Presupuesto de 1929-1930.

30 Diario Oficial, Tomo 96, núm. 147, 28 de junio de 1924, 1380; Diario Oficial, Tomo 86, núm. 140, 28 de junio de 1925, 1328; Diario Oficial, Tomo 100, núm. 42, 28 de junio de 1926, 1142 .

31 Por supuesto, había excepciones, sobre todo entre los asalariados especializados. Así, el fontanero municipal de Santa Tecla pasó de ganar 45 colones mensuales (540 anuales) en 1916 a 90 colones mensuales en 1932 (1,080 anuales), lo cual estaba ligado a la expansión de este servicio básico en ese transcurso, dado el proceso de urbanización en esta localidad y, en general, en las ciudades más grandes del país, lo que implicaba una alta demanda de este oficio particular. Archivo Municipal de Santa Tecla, Libros de actas municipales, libro de 1915-1916, 5 de enero de 1916; Archivo Municipal de Santa Tecla, Libros de actas municipales, libro de 1928-1933, 7 de enero de 1932. 
de los salarios. Por ejemplo, es dificil pensar que para los zapateros, durante la Gran Guerra, las subsistencias y sus tribulaciones fueran una complicación dramática, según el relato de Miguel Mármol en la novela de Roque Dalton. Empero, la causa detrás de sus mejores ingresos fue un aumento de la demanda por la interrupción de las importaciones de zapatos, y no un aumento de salarios:

«La demanda de mano de obra era enorme y los trabajadores del ramo comenzaron a florecer económicamente, a vestir bien, a tener dinero en el bolsillo, a beber el mejor guaro, a usar magnolias de a cinco pesos en la solapa, a fumar habanos (sic) legítimos, a pasear por los parques con capa vueluda y pistola conchanácar en la pretina, etc..132

Además, no se debe descartar que algunos miembros de los sectores populares urbanos tuvieran ingresos extra, como podía ser el caso de aquellos que tuvieran acceso a tierras y cultivos de subsistencia o de exportación, como notaba Antonio Acosta a finales del siglo XIX ${ }^{33}$. Ciertamente, ni las bonanzas duraron tanto tiempo ni los que tenían ingresos externos eran un grupo mayoritario. Acabada la guerra, la situación se volvió dificil para los zapateros y otros oficiales, como consigna el mismo Mármol ${ }^{34}$. Como demostraron las huelgas de los operarios de talleres de gremios y de otros asalariados de la década de los 20 , incluyendo los zapateros, las tarifas consuetudinarias definidas para los oficios fueron una loza dificil de mover en las negociaciones con las patronales, no siempre exitosas.Y, como se expresó en el apoyo de las vendedoras de los mercados a estas movilizaciones, la mejora o el empeoramiento del ingreso de otros sectores populares urbanos

32 Roque Dalton, Miguel Mármol: los sucesos de 1932 en El Salvador (Melbourne: Ocean Sur, 2007), pág. 67.

33 Acosta menciona el caso de un zapatero de Santa Ana de apellido Caballero, que poseía pequeñas tierras de café y tenía además problemas de crédito y deudas. Antonio Acosta Rodríguez, Los orígenes de la burguesía de El Salvador, 298.

34 Roque Dalton, Miguel Mármol: los sucesos de 1932 en El Salvador, pág. 68. 
repercutían en los propios ingresos de los sectores populares vinculados al comercio $^{35}$.

Estas limitaciones salariales de los artesanos y obreros son expuestas en detalle en la tesis de uno de los discípulos de Pedro Fonseca, Alirio Augusto Castro, titulada Datos para la economía social salvadoreña, de 1922. Castro presenta un diagnóstico de las condiciones de vida de los artesanos y obreros a partir de una encuesta trasladada a los trabajadores de San Salvador, la cual incluye una exploración de sus ingresos ${ }^{36}$. Como se puede comprobar en el Cuadro 3, los panaderos eran los que recibían un mejor pago y eran los únicos artesanos-obreros con ingresos superiores a los mencionados carteros de Santa Tecla. Los peor pagados eran los albañiles y peluqueros con salarios que rondaban los 300 colones anuales. Ahora bien, como demuestra el Cuadro 4, mayor ingreso no equivalía necesariamente a un salario más alto y, confirmando las observaciones de Mármol, dependía más bien de la demanda: los panaderos ganaban más porque trabajaban en promedio 198 días y 365 noches y, en realidad, tenían el salario diario más bajo, de 2 pesos. El resto de oficios tenía, en su mayoría, 48 días de descanso al año. Los artesanos mejor pagados eran los carpinteros, con 3 colones al día, aunque con menor demanda —o mayor capacidad de negociación con la patronal— con sus 72 días de descanso.

\footnotetext{
35 Luis Rubén González Márquez, «Política popular contenciosa: movilización social y hegemonía en El Salvador, 1919-1932», 77-79.

36 Siguiendo los pasos de la Demografía salvadoreña de su mentor y sus preocupaciones alrededor del salario y la subsistencia de los campesinos salvadoreños, la tesis de Castro (1922) se centró en los obreros, entendidos como los trabajadores de oficios, y en ofrecer lo que él consideró una alternativa: la economía social, una especie de ciencia e ingeniería social de la «felicidad» y la cohesión social, sin duda imbuida en una filosofia de utopismo socialista. Alirio Augusto Castro, «Datos para la economía social salvadoreña» (Tesis doctoral en Jurisprudencia y Ciencias Sociales, Universidad de El Salvador, 1922).
} 
Cuadro 3: Ingresos anuales de las familias de artesanos-obreros en San Salvador (en colones) 1922

\begin{tabular}{|c|c|c|c|c|c|c|}
\hline $\begin{array}{l}\text { Fuente de } \\
\text { ingresos }\end{array}$ & Zapateros & Sastres & Peluqueros & Tipógrafos & Albañiles & $\begin{array}{c}\text { Carpin- } \\
\text { teros }\end{array}$ \\
\hline Hombre & 384 & 431 & 312 & 350 & 300 & 432 \\
\hline Mujer & 180 & 180 & 184 & 180 & 180 & 180 \\
\hline $\begin{array}{c}\text { Hijo } \\
\text { o hija } \\
\text { menor de } \\
\text { edad }\end{array}$ & 144 & 144 & 144 & 144 & 144 & 144 \\
\hline Totales & 708 & 756 & 636 & 674 & 624 & 756 \\
\hline
\end{tabular}

Fuente: Alirio Augusto Castro, «Datos para la economía social salvadoreña» (Tesis doctoral en jurisprudencia y ciencias sociales, Universidad de El Salvador, 1922)

\section{Cuadro 4: Salarios (en colones) y jornadas de trabajo de los artesanos-obreros de San Salvador, 1922}

\begin{tabular}{|c|c|c|c|c|c|c|c|c|}
\hline \multirow[b]{2}{*}{$\underbrace{\mathscr{0}}_{0}$} & \multicolumn{2}{|c|}{ Salario máximo } & \multicolumn{2}{|c|}{ Salario mínimo } & \multirow{2}{*}{$\begin{array}{l}\text { Días de } \\
\text { trabajo }\end{array}$} & \multirow{2}{*}{$\begin{array}{l}\text { Horas } \\
\text { de } \\
\text { trabajo } \\
\qquad \begin{array}{l}\frac{\pi}{6} \\
\vdots\end{array}\end{array}$} & \multirow{2}{*}{$\begin{array}{l}\text { Días de } \\
\text { trabajo }\end{array}$} & \multirow{2}{*}{$\begin{array}{l}\text { Días de } \\
\text { des- } \\
\text { canso }\end{array}$} \\
\hline & 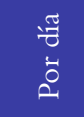 & ثँ & $\begin{array}{l}\frac{\pi}{6} \\
\stackrel{0}{0} \\
\stackrel{0}{0}\end{array}$ & 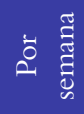 & & & & \\
\hline Zapateros & 2.75 & 16.50 & 1.25 & 7.50 & 6 & 10 & 317 & 48 \\
\hline Sastres & 2 & 12 & 1.50 & 9 & 6 & 10 & 317 & 48 \\
\hline Peluqueros & 2 & 13 & 1 & 6.50 & $61 / 2$ & 10 & 317 & 48 \\
\hline Tipógrafos & 2.50 & 15 & 1.25 & 7.50 & 6 & 8 & 293 & 72 \\
\hline Albañiles & 2 & 12 & 1 & 6 & 6 & 10 & 293 & 72 \\
\hline Carpinteros & 3 & 18 & 1 & 6 & 6 & 10 & 293 & 72 \\
\hline Panaderos & 2 & 14 & 1.50 & 10.50 & 7 & 12 & $\begin{array}{c}365 \\
\text { (noches) }\end{array}$ & 137 \\
\hline
\end{tabular}

Fuente: Alirio Augusto Castro, «Datos para la economía social salvadoreña» (Tesis doctoral en jurisprudencia y ciencias sociales, Universidad de El Salvador, 1922). 
Con Castro queda expuesta la disparidad de salarios por género y edad de las personas dedicadas a los oficios. El salario de las mujeres era apenas superior a la mitad del salario de los hombres en la mayoría de gremios, con la excepción de sastres, carpinteros y panaderos, en los que era un poco menos de la mitad. Los menores de edad (los aprendices) recibían un pago equivalente a 144 colones. Es lógico inferir que el problema del aprovisionamiento básico de estos sectores estuviera agravado por el inferior salario de las mujeres y los niños; especialmente, si se toma en cuenta el crecimiento de ilegitimidad infantil durante esos años y, por lo tanto, de familias monoparentales con la madre como única jefa de hogar. Castro observaba respecto a los salarios de las mujeres: «Lo que ganan trabajando todos los días del año (15 colones mensuales) es terriblemente mezquino, pues apenas si les alcanza para engañar el hambre» ${ }^{37}$.

Algunas descripciones posteriores, lastimosamente sin ofrecer cifras específicas, indican una caída del ingreso de los sectores populares urbanos ligada a la crisis económica de 1931-1933 y una leve recuperación en la década de los 30. Como señala Bulmer-Thomas, con la crisis creció el desempleo y bajó la demanda de los bienes y servicios producidos en las ciudades, por lo que se experimentó una contracción dramática del ingreso real de los trabajadores urbanos ${ }^{38}$. La única ventaja que afrontaron los habitantes de las ciudades fue que, al mismo tiempo, bajaron los precios de los alimentos (ver Gráficos 1-6). Esta situación de bajos salarios, reducción del empleo y alimentos baratos sólo se estabilizó lentamente a lo largo de la década de los $30^{39}$. El mayor drama de descenso de ingresos en esta crisis económica no se vivió en las ciudades a un nivel comparable lo que sucedió en el campo,

37 Alirio Augusto Castro, «Datos para la economía social salvadoreña», 29; Pedro Fonseca, Demografía salvadoreña, 66 y 67. Las disparidades de género y las relaciones de poder asociadas son una deuda pendiente de la historiografia salvadoreña. Una aproximación pionera de las relaciones de poder de género y la gestión del cuerpo femenino entre los sectores populares urbanos se encuentra en: Patricia Alvarenga, Cultura y ética de la violencia: El Salvador, 18801932 (San José: EDUCA, 1996).

38 Bulmer-Thomas, La economía política de Centroamérica desde 1920, 75-76.

39 Una situación análoga, con las diferencias de dimensión de la población urbana, a lo que sucedía en los países centrales, Estados Unidos y Europa: desempleo y bajos precios de alimentos. Eric Hobsbawm, Historia del siglo XX: 1914-1991 (Barcelona: Crítica, 1995), 100-101. 
donde se paralizaron las labores cafetaleras, se monetarizaron las obligaciones de los apareceros y colonos y se externalizaron hacia ellos los costos de la crisis, lo que resultó particularmente explosivo en la región occidental con sus limitaciones en el acceso a tierras ${ }^{40}$.

Ahora bien ¿Qué significaron concretamente estas tendencias de los ingresos para el consumo de los sectores populares urbanos? ¿Cuál era el comportamiento de los precios corrientes de las subsistencias en el período de guerras y entreguerras? Gracias a algunas fuentes sobre los precios de artículos básicos podemos hacernos una idea para años y situaciones específicas. Ese es el caso del Cuadro 5, que resume el precio de unos cuantos bienes básicos en el mercado Santa Tecla (en marzo y abril de 1916) reportados en informes de policía.

40 Este es un listado mínimo que excluye, por ejemplo, productos cárnicos. Por otro lado, refleja la preocupación de las autoridades por vigilar semanalmente, a través de sus agentes de policía, el comportamiento de los precios de los productos alimenticios básicos (una práctica común en los informes de policía, como veremos, por el peligro de crecimiento súbito y las escaseces). El único producto que excluimos fue la fanega de sal, que pasó de 15 colones, en marzo de 1916, a 16 colones al siguiente mes por no encontrar un estándar adecuado de conversión a una medida de peso. 


\section{Cuadro 5: Precios corrientes de bienes comestibles esenciales en Santa Tecla en marzo-abril de 1916 (en pesos) $^{41}$}

\begin{tabular}{|c|c|c|}
\hline \multirow{2}{*}{ Producto } & \multicolumn{2}{|c|}{ Precio } \\
\hline & Marzo & Abril \\
\hline Arroz (libra) & 0.04 & 0.04 \\
\hline Azúcar blanca (libra) & 0.06 & 0.05 \\
\hline Frijoles negros (libra)^ & 0.49 & 0.44 \\
\hline Leche (botella) & 0.27 & 0.29 \\
\hline Maíz desgranado (libra)^ & 0.16 & 0.15 \\
\hline Manteca (libra) & 0.88 & 0.88 \\
\hline Trigo (libra)^ & 0.45 & 0.45 \\
\hline Total & 1.83 & 2.3 \\
\hline
\end{tabular}

Fuente: AGN, Fondo Gobernación política departamental de La Libertad, sección Documentos Buenos, caja 46, «Informes de policía», 5 de marzo, 18 de marzo, 25 de marzo, 15 de abril, 22 de abril y 29 de abril de 1916.

*Aproximado de fanegas a libras según metrología para México de David Frye.

De un mes a otro, el precio de todos los productos enlistados se había modificado; algunos aumentaron de precio y otros se redujeron y, en general, el costo de este listado había aumentado 47 centavos, un 25 por ciento de marzo a abril. Si se compara con el salario de ese año de los carteros de la misma municipalidad (de 480 pesos anuales), el resultado es que estos trabajadores no podían pagar por todos los productos de este listado con su ingreso diario, equivalente a 1.43 centavos: para marzo les hacía falta 40 centavos y para abril, 87 centavos. Si compraban ese mismo listado una vez a la semana, éste hubiera representado el 18.3 por ciento y el 23 por

41 Este es un listado mínimo que excluye, por ejemplo, productos cárnicos. Por otro lado, refleja la preocupación de las autoridades por vigilar semanalmente, a través de sus agentes de policía, el comportamiento de los precios de los productos alimenticios básicos (una práctica común en los informes de policía, como veremos, por el peligro de crecimiento súbito y las escaseces). El único producto que excluimos fue la fanega de sal, que pasó de 15 colones, en marzo de 1916, a 16 colones al siguiente mes por no encontrar un estándar adecuado de conversión a una medida de peso. 
ciento de sus ingresos de marzo y abril, respectivamente. Mientras, si nos concentramos en el maíz y en los frijoles, a partir de la observación de Fonseca acerca de su consumo diario por los campesinos — 0.56 libras de maíz y 0.59 de frijoles-, es posible inferir que el gasto diario en estos dos granos básicos alcanzó por lo menos 0.38 pesos en marzo y 0.34 pesos en abril; es decir 26.57 por ciento y 23.77 por ciento del ingreso diario de los carteros tecleños. Si bien, en general, frente a los artesanos mejor pagados de 1888 la situación de los carteros tecleños en 1916 era más favorable, estos últimos todavía tenían que gastar aproximadamente una cuarta parte de sus recursos para alcanzar una cantidad mínima y precaria de los dos granos básicos.

Un poco más de un lustro después, en el estudio de Castro de 1922, se confirma esta mejoría relativa frente a la situación de finales del siglo XIX e, incluso, aparecen algunos ecos de la leve tendencia a la baja de los granos básicos de 1919-1921, aunque queda en cuestión qué tan significativo fue ese aumento para mejorar sustancialmente la capacidad adquisitiva de estos sectores populares. El nivel de detalle del estudio de Castro permite conocer otros gastos cotidianos y algunos aspectos de la cultura del consumo vigente entre los trabajadores de oficios artesanales. Como consigna el Gráfico 7, la alimentación era el segundo mayor gasto de las familias de obreros y consumía el 22.25 por ciento de su ingreso promedio; solo era superado por el gasto en licor, el cual equivalía al 35.60 por ciento de todo el ingreso, amén de la epidemia de alcoholismo de esos años ${ }^{42}$. Una anotación de Castro sobre el alcoholismo evidencia el drama que este podía plantear para la sobrevivencia del núcleo familiar: señala que muchos obreros piden adelantado dinero "para emborracharse y dejan sufrir a sus mujeres e hijos las torturas de la desnudez y el hambre" ${ }^{43}$.

\footnotetext{
42 Tan fervientemente denunciada por intelectuales como Alberto Masferrer o funcionarios como José Esperanza Suay, en una crítica moralista social que también hallaba eco en Castro. Carlos Loucel Lucha, "Crisis, aguardiente y café (1898-1930)", en Los estancos, las prácticas monopólicas y las rentas del Estado en El Salvador, ed. Pedro Escalante Arce y Eugenia López Velásquez (San Salvador: Dirección de Publicaciones e Impresos, Consejo Nacional para la Cultura y el Arte, 2008), 227-270.

43 Alirio Augusto Castro, «Datos para la economía social salvadoreña», 29.
} 


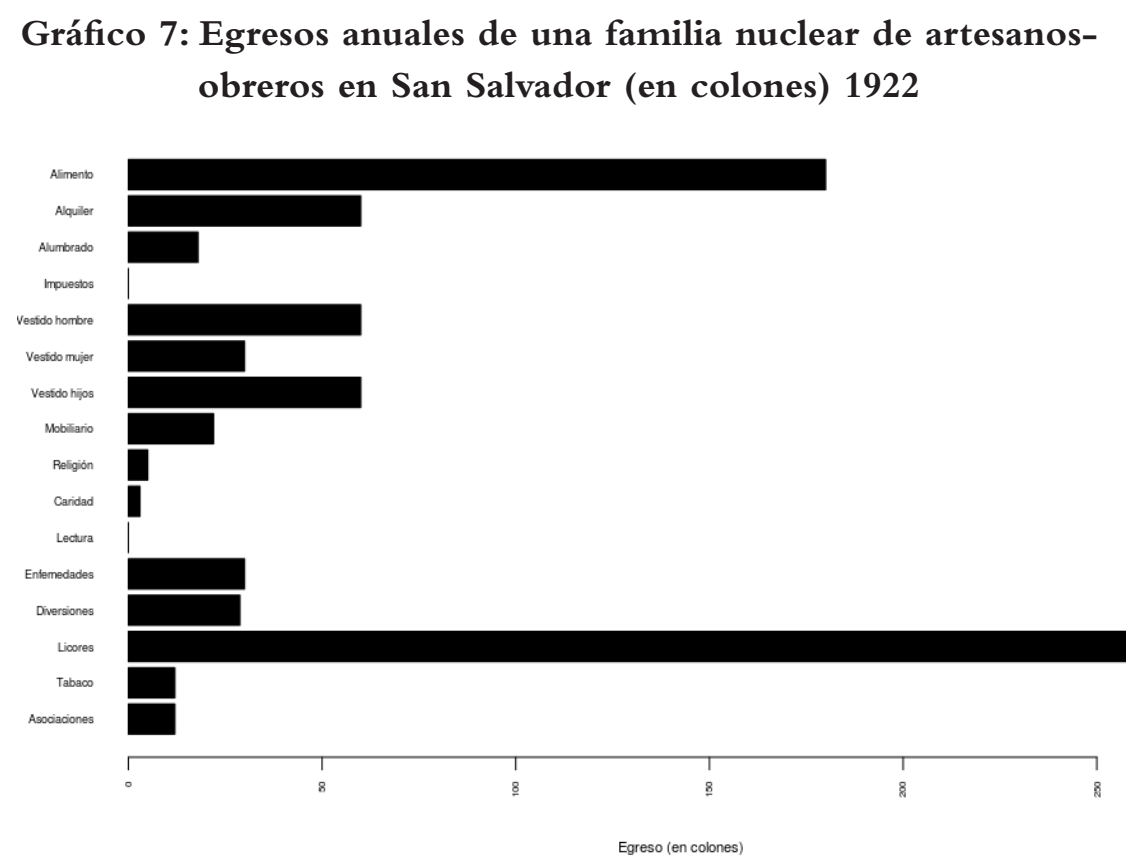

Fuente: Alirio Augusto Castro, «Datos para la economía social salvadoreña» (Tesis doctoral en jurisprudencia y ciencias sociales, Universidad de El Salvador, 1922).

Aparte de la alimentación y el licor, los ingresos de los sectores populares urbanos — en concreto de los artesanos y obreros- recibían las presiones de otras necesidades básicas como la vestimenta, la vivienda y el reciente alumbrado público que anualmente podían ascender a 280 colones, si se trataba de un núcleo familiar. Además, este ingreso también estaba sujeto a los vaivenes de la salud y los accidentes, un tema de alta preocupación para estos grupos ${ }^{44}$, por lo que otros gastos se orientaban hacia mecanismos novedosos (las organizaciones obreras) o tradicionales (limosnas, bajo el principio de reciprocidad) de seguridad social o para atender directamente enfermedades cuando aparecieran, los cuales ascendían a 50 colones. Al cruzar el total de todos los gastos incluyendo los de ocio, el tabaco y el alcohol,

44 Luis Rubén González Márquez, «Sociabilidad y organizaciones artesanales-obreras. La Sociedad de Artesanos El Porvenir de Santa Tecla, 1902-1932». 
estos alcanzaban en promedio los 860.8 colones. Ninguno de los salarios registrados por Castro, tanto individuales como para cada oficio asumiendo una familia de 3 con un hijo o hija que fuera aprendiz, llegaba a esta cifra; mucho menos el salario de los carteros tecleños para este año, el cual apenas cubría un poco más de la mitad. Solo el gasto de alimentación era equivalente al salario de las mujeres dentro de los oficios, y solo considerando los gastos de alimentación, otras necesidades básicas y en prevención o atención de enfermedades, con un total de 510, sobrepasaba en 210 colones el ingreso de los albañiles, en 78 colones el ingreso de los carpinteros y en 40 colones el de los carteros de Santa Tecla. De una hipotética familia de madre y padre zapateros e hijo o hija aprendiz, del mismo oficio, significaba el 72.03 por ciento de sus salarios conjuntos. Si esta familia se dedicaba a la panadería, sería 61.89 por ciento y si se dedicaba a la peluquería, de 80.19 por ciento. El crédito usurario, la presión sobre los recursos familiares o el trabajo extra seguramente eran empleados como mecanismos para compensar las falencias del ingreso.

En años posteriores, es posible notar los efectos de una mayor estabilidad y capacidad adquisitiva al contrastar ingresos y precio de las subsistencias, sobre todo en el marco de los problemas descritos que aparejó la crisis de 1929-1933. Aun así, el gasto en las subsistencias no dejó de representar una proporción relevante de los gastos de estos grupos. En contraste con las décadas anteriores, la escasez de datos sobre salarios e ingresos son compensados por los detallados informes de los promedios nacionales de los precios corrientes en los anuarios estadísticos de 1935-1939 (Cuadro 6), cuya misma elaboración, por cierto, demuestra la relevancia que el asunto mantenía para el Estado ahora dirigido por la dictadura militar de Maximiliano Hernández Martínez. En el Cuadro 7 se contrastan los precios de estos productos con el salario de los carteros municipales de Santa Tecla hasta 1931 para, al menos, inferir el porcentaje de capacidad de compra de todos los productos enlistados y el porcentaje de salario que representaban las cantidades diarias mínimas de frijoles y maíz, según los referidos datos de Fonseca. 
Cuadro 6: Precios corrientes de bienes comestibles esenciales en El Salvador, 1935-1939 (en colones) ${ }^{45}$

\begin{tabular}{|l|c|c|c|c|c|}
\hline \multicolumn{5}{|c|}{ Precio } \\
\hline Producto/Unidad & $\mathbf{1 9 3 5}$ & $\mathbf{1 9 3 6}$ & $\mathbf{1 9 3 7}$ & $\mathbf{1 9 3 8}$ & $\mathbf{1 9 3 9}$ \\
\hline $\begin{array}{l}\text { Azúcar de pilón } \\
\text { (kilogramo) }\end{array}$ & 0.31 & 0.26 & 0.33 & 0.30 & 0.32 \\
\hline $\begin{array}{l}\text { Arroz del país } \\
\text { (kilogramo) }\end{array}$ & 0.17 & 0.13 & 0.18 & 0.15 & 0.12 \\
\hline $\begin{array}{l}\text { Frijoles negros } \\
\text { grandes (kilogramo) }\end{array}$ & 0.13 & 0.13 & 0.22 & 0.19 & 0.14 \\
\hline $\begin{array}{l}\text { Maíz desgranado } \\
\text { (kilogramo) }\end{array}$ & 0.08 & 0.5 & 0.12 & 0.07 & 0.5 \\
\hline $\begin{array}{l}\text { Harina del país } \\
\text { (kilogramo) }\end{array}$ & 0.33 & 0.38 & 0.46 & 0.42 & 0.41 \\
\hline Leche (botella) & 0.12 & 0.11 & 0.14 & 0.11 & 0.11 \\
\hline $\begin{array}{l}\text { Manteca } \\
\text { (kilogramo) }\end{array}$ & 1.24 & 0.83 & 1.18 & 0.88 & 0.80 \\
\hline Gallinas (cabeza) & 0.73 & 0.63 & 0.70 & 0.70 & 16.18 \\
\hline Total & $\mathbf{3 . 1 1}$ & $\mathbf{2 . 9 7}$ & $\mathbf{3 . 3 3}$ & $\mathbf{2 . 8 2}$ & $\mathbf{1 8 . 5 8}$ \\
\hline
\end{tabular}

Fuentes: Dirección General de Estadística, Anuario estadístico de 1935-1939

(San Salvador: Imprenta Rafael Reyes, 1936-1940)

45 Conviene destacar que es una selección nuestra de los productos de menor costo y calidad enlistados en los Anuarios estadísticos. 


\section{Cuadro 7: Relación costo de comestibles esenciales y salario de carteros municipales de Santa Tecla, 1935-1939}

\begin{tabular}{|l|c|c|c|c|c|}
\hline \multicolumn{5}{|c|}{ Precio } \\
\hline Producto/Unidad & 1935 & 1936 & 1937 & 1938 & 1939 \\
\hline $\begin{array}{l}\text { Porcentaje de } \\
\text { compra de listado de } \\
\text { bienes esenciales en } \\
\text { salario diario }\end{array}$ & $217.48 \%$ & $207.69 \%$ & $232.87 \%$ & $197.20 \%$ & $1,299.3 \%$ \\
\hline $\begin{array}{l}\text { Porcentaje de } \\
\text { compra de listado de } \\
\text { bienes esenciales en } \\
\text { salario semanal }\end{array}$ & $31.1 \%$ & $29.7 \%$ & $33.3 \%$ & $28.2 \%$ & $185.8 \%$ \\
\hline $\begin{array}{l}\text { Porcentaje de } \\
\text { consumo mínimo } \\
\text { de maíz y frijoles en } \\
\text { salario diario }\end{array}$ & $4.2 \%$ & $12.59 \%$ & $6.29 \%$ & $4.9 \%$ & $12.59 \%$ \\
\hline
\end{tabular}

Fuente: Dirección General de Estadística, Anuario estadístico de 1935-1939 (San Salvador: Imprenta Rafael Reyes, 1936-1940); Fonseca, Demografía salvadoreña, 1o ed. (San Salvador: Imprenta Rafael Reyes, s.f.), 54; y Archivo General de la Nación, Fondo Ministerio de Gobernación-del Interior, Ley de Presupuesto de 1929-1930.

El Cuadro 6 sugiere, a partir de una serie de 5 años, cómo las referidas variaciones cortoplacistas de los granos básicos eran una expresión de un comportamiento volátil más generalizado que involucraba a todos los víveres y se trasladaba directamente a los consumidores. Por ejemplo, el kilo de maíz desgranado pasó de valer 8 centavos (en 1935) a 50 centavos al siguiente año; curiosamente, en el Gráfico 1 el precio al por mayor del maíz mostraba un descenso, por lo cual el aumento de precios había sido generado en la cadena de distribución. Aparte de los granos, también la carne más barata, la de gallina, mostró un precio inestable: de tener un precio de menos de un colón por cabeza hasta 1938, pasó a sobrepasar los 18 colones en 1939. Los resultados del Cuadro 7 indican los cambios y continuidades en la capacidad adquisitiva de los sectores populares urbanos al final del período de entreguerras. Frente al salario de los carteros, los listados de precios de bienes 
básicos del Cuadro 6 duplicaban el ingreso de estos trabajadores urbanos, y si compraban ese mismo listado mínimo una vez por semana representaba alrededor de un tercio, aunque ello también está ligado a la mayor diversidad de productos considerados. Con todo, es innegable la reducción de los precios de los granos básicos y la relativa diversificación del consumo con respecto a la situación de 1888, dado que podían cubrir el consumo diario mínimo de frijoles y maíz descrito por Fonseca con menos de la décima parte de su salario. No obstante, la variabilidad de precios obliga a a la cautela al describir cualquier mejora y, tanto en 1936 como en 1939, el aumento del precio del maíz hizo ascender el porcentaje de gasto en este consumo mínimo hasta el 12.59 por ciento.

En síntesis, los indicadores de precios corrientes y salarios recopilados permiten una aproximación concreta a las precariedades cotidianas que signaban la vida de los sectores populares urbanos. Conviene recordar que esta situación no era producto de uno o varios defectos sistémicos o de herencias que lastraban la economía de mercado en El Salvador de entreguerras. Por el contrario, el alto precio de los productos de consumo está directamente relacionado con rasgos que caracterizaban el régimen de acumulación agroexportador vigente: la expansión de la agricultura comercial; el carácter regresivo de la estructura tributaria — que presionaba a los consumidores- y el control de algunos grupos de la oligarquía cafetalera, en confluencia con el Estado, de las cadenas de provisión de bienes para el mercado interno. ${ }^{46}$ Asimismo, la tendencia a la baja y la permanencia de los salarios, con la consiguiente desvalorización del trabajo, constituían un factor central en el proceso de producción, así como un objetivo político de primer $\operatorname{orden}^{47}$. Aun con la distancia que imponía la frontera interno-colonial entre los trabajadores rurales y los citadinos, este principio de explotación se extendió al resto de mercado laboral, al erigirse en sentido común de la cultura

46 Antonio Acosta Rodríguez, Los orígenes de la burguesía de El Salvador; Carlos Loucel Lucha, «Crisis, aguardiente y café (1898-1930)».

47 Héctor Lindo-Fuentes, La economía de El Salvador en el siglo XIX; Antonio Acosta Rodríguez, Los orígenes de la burguesía de El Salvador. 
productiva de la nueva disciplina liberal del cuerpo de los trabajadores ${ }^{48}$. La variabilidad de los precios corrientes y la inmovilidad salarial planteaban dificiles dilemas cotidianos a los habitantes pobres de las ciudades, especialmente cuando irrumpían los altos encarecimientos. ${ }^{49}$

\section{La escasez y los encarecimientos agudos: las contradicciones del Estado liberal}

En consecuencia con su variabilidad en el corto plazo, las alzas agudas y repentinas de los precios de los artículos de primera necesidad, con el aumento súbito del costo de la vida, eran la expresión más patente de la fragilidad en la reproducción material de los sectores populares urbanos. Aunque en principio eran momentos inesperados, sin una periodicidad fija, su frecuencia en la primera mitad del siglo XX los ubicaba definitivamente en el horizonte de lo posible. En la discusión pública de estos años se les consideraba como sinónimo escasez de granos básicos y como encarecimientos de importaciones, adjudicando de paso una causalidad que no estaba tan clara.

El Gráfico 8 expone una línea de tiempo de las escaseces de granos y los encarecimientos de importaciones más acentuados (entre 1900 y 1940), al menos aquellos con mayor resonancia en la opinión pública y que justificaron su reporte por funcionarios estatales. En este período de 40 años, hubo 9 episodios de este tipo, con un promedio de un encarecimiento cada 4 años y medio. Los encarecimientos de las importaciones se concentraron en el período de la Primera Guerra Mundial, en una clara resonancia de las perturbaciones en el comercio internacional por este conflicto. Peor aún, en

48 No resulta casual que su crítica fuera un elemento discursivo que permitiera un diálogo común en la movilización social de los 20. Jeffrey Gould y Aldo Lauria-Santiago, 1932: rebelión en la oscuridad.

49 Queda la duda de cómo los sectores populares urbanos sufragaban los gastos cuando sobrepasaban su capacidad de pago, ya fuera por algún revés cotidiano, enfermedad o por un aumento repentino de los precios: además la salida dramática del hambre, probablemente se fortalecían las redes de endeudamiento y usura, mismas que remiten tanto a mecanismos informales de acumulación económica (pendiente de exploración para El Salvador de los siglos XIX y XX) como a las relaciones patrón-cliente. Erik Ching, «From clientelism to militarism: The state, politics and authoritarianism in El Salvador, 1840-1940». 
1914, al inicio de ese conflicto bélico, al aumento del costo de las importaciones se le sumó una escasez de granos básicos ${ }^{50}$. No resulta una casualidad la consiguiente mejora de las estadísticas oficiales sobre precios de los bienes básicas, como una medida para vigilar estas posibles alzas.

\section{Gráfico 8: línea de tiempo de episodios de escasez de granos y encareci- miento agudo de importaciones en El Salvador 1900-1940}

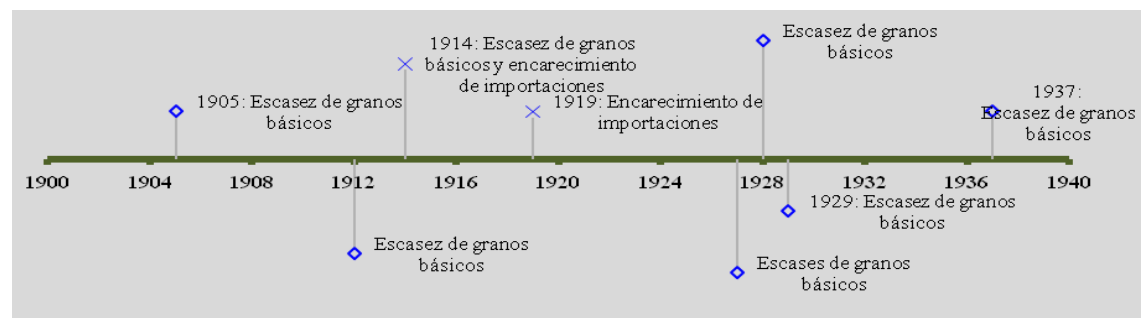

Fuentes: Archivo General de la Nación, Biblioteca especializada en historia, Ministerio de Gobernación, Fomento y Agricultura, Memoria de Gobernación, Fomento, Agricultura y Trabajo, 1929; Carlos Loucel Lucha, «Crisis, aguardiente y café (1898-1930)», en Pedro Escalante Arce y Eugenia López Velásquez (eds.), Los estancos, las prácticas monopólicas y las rentas del Estado en El Salvador (San Salvador: Dirección de Publicaciones e Impresos, 2008); Archivo General de la Nación (AGN), Fondo Gobernación política departamental de La Libertad, sección Libros, 5-21, «Libro de órdenes telegráficas, oficios circulares, telegramas parciales y oficios parciales, 1927-1929».

Entonces, ¿En qué consistía un aumento súbito del precio de los bienes en el período de entreguerras? ¿Cómo afectaron concretamente a los sectores populares urbanos? ¿Cuáles fueron las reacciones de éstos, las del Estado y las de las clases dominantes? Aunque una respuesta plena sobrepasa los límites de este trabajo, las fuentes de archivo a nivel nacional — del depar-

50 La situación llegó a ser tan dramática ese año que hasta las asociaciones de obreros más moderadas de Santa Tecla se comprometieron en una protesta pública para que el Gobierno vendiera maíz "a precio de costo» y para que presionara a «los pudientes» para construir en «solares valdíos (sic)», y así aumentar los puestos de trabajo. Desafortunadamente, desconocemos qué otras respuestas hubo ante la situación de 1914. Luis Rubén González Márquez, «Sociabilidad y organizaciones artesanales-obreras. La Sociedad de Artesanos El Porvenir de Santa Tecla, 1902-1932», 186 y 187. 
tamento de La Libertad y de la prensa, en particular del Diario del Salvadorpermiten un abordaje inicial de estas cuestiones a partir del conocimiento detallado de la dinámica de la escasez de 1928.

Para contextualizar adecuadamente este caso, un primer aspecto a tomar en cuenta es el comportamiento de los precios de los granos básicos en 1928. Ese año representó uno de los picos más altos del costo del maíz, tanto a nivel nacional como en el departamento de La Libertad; igualmente, en esta región el frijol alcanzó el precio más alto del período 1928-1942 (ver gráficos 1,4 y 5). Además, el Gráfico 8 constata la ubicación de este aumento de precios en el medio de una coyuntura particularmente desgastante, pues hubo escasez de granos en los tres años seguidos de 1927-1929. A lo largo de 1928, el momento de escasez y de precios más altos de los granos básicos fue entre mayo y julio, en coherencia con el régimen de cosechas descrito en el Cuadro 1. El caso más preocupante fue el precio del maíz: en su punto más alto, en julio, costó 11.62 colones el quintal como promedio nacional, y en La Libertad llegó a ascender 18.5 colones el quintal ${ }^{51}$. Es decir, si bien la escasez y los altos precios se manifestaron a nivel nacional, fueron particularmente sentidos La Libertad. Lo mismo sucedió con la extensión temporal de este fenómeno, más marcada en este departamento.

En efecto, aunque las primeras menciones de problemas de aprovisionamiento de maíz y granos básicos a nivel nacional y de este departamento las encontramos en mayo ${ }^{52}$, su finalización fue divergente; a nivel nacional, la podemos ubicar en la segunda quincena del mes de agosto ${ }^{53}$. Mientras tanto, en el departamento de La Libertad continuó siendo una preocupación hasta finales de septiembre. Solo hasta el 24 de ese mes el gobernador de La

51 Dirección General de Estadística, Anuario estadístico de 1928 (San Salvador: Imprenta Rafael Reyes, 1929).

52 El 30 de ese mes, una circular del presidente del país al gobernador del departamento de La Libertad, que este asimismo trasladó a los alcaldes bajo su jurisdicción, informa del «alza inmoderada de los precios del maíz y los frijoles productos (sic) que son de nesecidad (sic) indispensable para la alimentación de las clases populares». AGN, Fondo Gobernación política departamental de La Libertad, sección Libros, 5-21, Libro de órdenes telegráficas, oficios circulares, telegramas parciales y oficios parciales, 1927-1929, 66.

53 Anónimo, «Robo en una de las ventas de maíz del gobierno», en Diario del Salvador, 2 de agosto de1928, 3 . 
Libertad le planteaba al ministro de agricultura la conveniencia de rebajar el precio del maíz que vendía el gobierno, a 12 colones el saco con todo y costal y a «\$11.25 en granel», porque, superada la escasez, «la existencia de maíz es bastante considerable; y al precio que actualmente se está expendiendo, no guarda relación con el que tiene en la plaza el maíz nuevo del país, máxime (sic) si se toma en cuenta que este [maíz] tiene mejor demanda $»^{54}$.

La cita anterior nos adelanta las respuestas gubernamentales a la escasez. Para comprender estas medidas, es necesario señalar las dificultades del gobierno para determinar el porqué de esa subida de precios y problemas de aprovisionamiento. Las respuestas de los funcionarios fueron variables en ese sentido. A veces culpaban a malas cosechas por plagas o el clima, pero la sombra del acaparamiento también se cernía sobre las autoridades; por ejemplo, en una nota del gobernador departamental de La Libertad, fechada el 2 de junio de 1928, y dirigida al alcalde de la municipalidad de Santa Tecla, aquél se contradice en su explicación del fenómeno: primero, apunta como causa de la escasez de maíz «a los estragos del chapulín». No obstante, cuando finaliza el documento, agrega: «Según datos concretos que el Supremo Gobierno ha recibido de los señores Gobernadores Departamentales de las cantidades de maíz existentes en cada población, y de los nombres de los dueños de las respectivas trojas; hay cantidad suficiente de maíz en toda la República». Por lo tanto, «la actual situación anormal creada por el alza de los precios no es más que obra de los acaparadores, contra quienes se emitirán órdenes terminantes y efectivas por el Ejecutivo» ${ }^{55}$.

La variedad de respuestas del gobierno, en su mayoría infructuosas, reflejan tanto esas limitaciones para determinar la causa de las alzas y, sobre todo, los compromisos y prioridades sociales e ideológicas del Estado más

54 AGN, Fondo Gobernación política departamental de La Libertad, serie Documentos Buenos, caja 49, Copias de correspondencia, 24 de septiembre de1928.

55 AGN, Fondo Gobernación política departamental de La Libertad, serie Documentos Buenos, caja 5, Copia de notas, 2 de junio de1928. 
que una «debilidad $»^{56}$. Es importante destacar que el Estado no fue indiferente a la difícil situación de los grupos subalternos urbanos; más aún, en las coyunturas críticas desplegó una considerable cantidad de recursos y se erigió como salvaguarda, en última instancia, del aprovisionamiento mínimo de la población de las ciudades. Esto lo obligó a traicionar el liberalismo clásico, con sus principios de libre mercado de trabajo, moneda y bienes, y a incorporar lo que Karl Polanyi había presenciado para la Europa de finales del siglo XIX: el surgimiento - e incorporación ideológica- de mecanismos proteccionistas a la sombra del liberalismo, precisamente para hacer frente, de forma práctica, a las contradicciones y peligros de la implementación de la ficción de libre mercado; en este caso concreto el de los productos alimenticios y bienes básicos ${ }^{57}$.

Sin embargo, el hecho de que el Estado no se preparara para situaciones críticas tan recurrentes, la pobre vocación en la persecución de los acaparadores y la ausencia de reformas para contener y solventar las alzas de precios - a diferencia de la firmeza con la cual reorganizó los factores de producción en función de la agricultura de exportación a finales del siglo XIX, por ejemplo- son un reflejo de las prioridades del Estado liberal. El Estado salvadoreño veía tensado su proyecto de construcción de hegemonía en estos episodios de escasez por las presiones de los sectores populares, los compromisos de clase en función de la acumulación capitalista y la asimilación del credo del liberalismo económico como parte de ese proyecto ideológico-político.

56 En ese sentido, coincidimos parcialmente con Acosta en su cuestionamiento a la tesis sobre la debilidad del Estado; más bien era un constructo complejo, débil en unas partes y situaciones, fuerte en otras, según proyecto económico y social de clase vigente desde mediados del siglo XIX. Nuestra discrepancia parcial se refiere a que ese constructo no era tan monolíticamente coherente con el dominio de clase de esa burguesía; también obedecía a un contradictorio proyecto ideológico con pretensiones hegemónicas - por lo tanto, con concesiones e intentos de formulación de marcos discursivos de negociación frente a determinados sectores, como los habitantes de las ciudades- y a la sedimentación de los resultados de la negociación con otros grupos. Como veremos, incorporar la ideología y estas sedimentaciones se vuelve crucial para entender la dinámica social frente a la escasez. Antonio Acosta Rodríguez, Los orígenes de la burguesía de El Salvador; Luis Rubén González Márquez, «Política popular contenciosa: movilización social y hegemonía en El Salvador, 1919-1932».

57 Karl Polanyi, La gran transformación los orígenes políticos y económicos de nuestro tiempo (México: Fondo de Cultura Económica, 2003), 208-221. 
En concreto, en la escasez de 1928, las respuestas del Estado fueron reactivas y graduales a medida que se desarrollaba el alza de precios de los granos básicos. Comenzó con las más sencillas y las menos contradictorias desde los principios de libre mercado: combatir el chapulín o apoyar al combate del chapulín que hacían los agricultores, o liberar de todo derecho de importación a los granos que escaseaban, como lo hicieron a finales de mayo de ese año las autoridades regionales y nacionales ${ }^{58}$. A continuación, desde julio debió flexibilizar el dogma liberal de no intervención del Estado e importar maíz de San Francisco y Nicaragua para venderlo al costo en todo el país ${ }^{59}$. Gracias a los documentos de La Libertad, conocemos que el mecanismo de reparto se hacía a través de los alcaldes municipales, quienes antes solicitaban la cantidad de maíz que necesitaban vender, con el objeto tanto de aprovisionar a la población más necesitada, como de forzar una reducción en el precio ${ }^{60}$. Esta medida no era en absoluto extraña en la época (tenemos evidencia que planteó igualmente en la escasez de $1912^{61}$ y en la de $1929^{62}$ ) y resultaba profundamente onerosa para las finanzas públicas, porque como consta en la Memoria de Gobernación, Fomento y Agricultura de este último año, «la mayor parte de ese maíz no fue posible venderlo sino a menor precio de su costo» ${ }^{63}$.

58 AGN, Fondo Gobernación política departamental de La Libertad, sección Libros, 5-21, Libro de órdenes telegráficas, oficios circulares, telegramas parciales y oficios parciales, 19271929,66 y 67.

59 Nótese que era precisamente lo que en 1914 le demandaba El Porvenir ¿̇Habrá sido este intervencionismo sedimentación de presiones y movilizaciones de los sectores populares urbanos? Anónimo, «El gobierno anuncia la llegada de varios miles de sacos de maíz», en Diario del Salvador, 3 de julio de 1928, 1.

60 En Santa Tecla, por ejemplo, hacia el 8 de agosto se habían realizado tres entregas, por las cuales pedía cuentas el gobernador al alcalde en una correspondencia. AGN, Fondo Gobernación política departamental de La Libertad, serie Documentos Buenos, caja 49, Copias de correspondencia, 8 agosto de 1928.

61 Anónimo, «Maíz Maíz Maíz», Diario del Salvador, 18 de julio de 1912,1.

62 Ministerio de Gobernación, Fomento y Agricultura, Memoria de Gobernación, Fomento, Agricultura y Trabajo, 1929,173-175.

63 Ministerio de Gobernación, Fomento y Agricultura, Memoria de Gobernación, Fomento, Agricultura y Trabajo, 1929, 175. Es decir, fue un subsidio en la práctica. 
En algunos momentos del alza de precios y la escasez de 1928, las rupturas con el molde del pensamiento económico liberal se volvían aún más patentes en el accionar gubernamental: los funcionarios y personeros estatales se plantearon controles de precios, por lo menos temporales o flexibles. Por ejemplo, en una nota del gobernador al alcalde y jefe de distrito de Santa Tecla del 11 de julio, aquél le informa de la regulación de precios que implementó el gobierno: el maíz tenía «un precio fijo de $\$ 1.25$ (colones) el medio almud». Sin embargo, más adelante aclara que no se trataba en absoluto de un precio taxativo fijado por el gobierno; por el contrario, volviendo a un repertorio de las facultades municipales coloniales, la orden gubernamental mandaba a controlar las injusticias en los precios de la plaza, de presionar informalmente a vendedores porque el valor se ajustara a la economía moral ${ }^{64}$ : «El precio de maíz en el mercado, es hoy día de tres colones el medio almud; nada querría decir que las personas que se ocupen de ello, lo vendieren hasta $\$ 1.50$ el medio» ${ }^{65}$. Debemos notar que esa presión por el precio justo estaba dirigida a los vendedores al por mayor.

Cuando cobró fuerza la hipótesis del acaparamiento, el gobierno - en ese momento dirigido por Pío Romero Bosque- recurrió a la reprensión de los acaparadores. Los agentes gubernamentales declararon en variadas oportunidades la condena moral a éstos, junto a anuncios de variadas iniciativas para perseguirlos y reprimirlos, sin implementarlas efectivamente $^{66}$. Esto último resulta asombrosamente contradictorio con los daños que estos encarecimientos causaban en la economía pública y en la de los sectores populares urbanos, y también con el conocimiento del Estado de las

64 Lina Eugenia Barrios Escobar, Tras las huellas del poder local: la Alcaldía Indígena en Guatemala, del siglo XVI al siglo XX, (Guatemala: Universidad Rafael Landívar-Instituto de Investigaciones Económicas y Sociales, 2001), 75-83; Edward Palmer Thompson, «La economía moral de la multitud en la Inglaterra del siglo XVIII", en Tradición, revuelta y conciencia de clase (Barcelona: Crítica, 1984), 62-134.

65 AGN, Fondo Gobernación política departamental de La Libertad, serie Documentos Buenos, caja 49, Copias de correspondencia, 11 de julio de 1928.

66 En julio de ese año, el ministro de gobernación le decía al gobernador: «Tengo noticias acaparadores maíz continúan abusando (sic) no obstante las disposiciones de este Ministerio». AGN, Fondo Gobernación política departamental de La Libertad, serie Documentos Buenos, caja 49, Copias de correspondencia, 14 de julio de 1928. 
modalidades de acción de los acaparadores. Casi desde el inicio de la escasez de 1928, el 2 de junio, el gobernador de La Libertad había enviado esta carta al alcalde de Santa Tecla:

«Para evitar lo más posible que se encarezca el maíz, frijol y arroz, granos de primera necesidad; ruego a Usted, impartir sus órdenes, tanto a los agentes de la Policía Municipal, como a los Comisionados Cantonales; para que procedan a retirar a todas aquéllas personas que se ocupen de acaparar los granos mencionados, en las entradas de la población y dejen libre paso a los vendedores de dichos cereales para que puedan llegar hasta el mercado a efectuar sus ventas; con lo cual creo se conseguirá más bajo precio» ${ }^{67}$.

Sin embargo, eran infrecuentes las noticias sobre la captura de acaparadores. En La Libertad, el 24 de julio de $1928^{68}$, se reportó el apresamiento de una señora llamada Felícita Platero, quien «sale a acaparar maíz a la entrada del Camino que de Colón conduce a ésta, en el lugar llamado el plan. Ha comprado a $\$ 9.00$ la fanega en mazorca y hace la reventa a 3 mazorcas por $\$ 0.05 »^{69}$. Es dificil no sospechar que Platero más bien intentaba obtener algunos beneficios de una situación de crisis de precios instalada por otros acaparadores con capacidad de acción a mayor escala. Para poder forzar subidas de precios del mercado se debía contar con los recursos necesarios para la compra de todo el producto a los agricultores a gran escala; además, contar con los suficientes clientes, un punto fijo de venta y conocimiento de la cadena de distribución. Por esta razón resulta plausible que medianos y grandes negociantes, tal vez con vínculos con las clases dominantes y el Estado, estuvieran involucrados en el acaparamiento ${ }^{70}$. Aparte de los compromisos de clase, existía un problema ulterior: así como los monopolios,

67 AGN, Fondo Gobernación política departamental de La Libertad, serie Documentos Buenos, caja 49, Copias de notas, 2 de junio de 1928.

68 Anónimo, «5 días presa por comprar maíz», Diario del Salvador, 11 de julio de 1928, 1.

69 AGN, Fondo Gobernación política departamental de La Libertad, serie Documentos Buenos, caja 5, Copia de correspondencia, 24 de julio de 1928.

70 Cabe preguntarse cómo se puede explicar que un Estado que en tuvo la capacidad de efectuar la Matanza en 1932, no pudo perseguir frontalmente a acaparadores 5 años antes. 
en sentido estricto el acaparamiento era una paradoja de la organización del mercado de productos básicos según los principios de libre circulación de bienes y servicios ${ }^{71}$. Legislar efectivamente contra ella, más allá de algún decreto extraordinario, implicaba poner en cuestión esos presupuestos ideológicos del liberalismo económico vigente.

En consecuencia, en los momentos críticos de las alzas de precios de 1928, ante las contradicciones que le impedían combatir el acaparamiento, los personeros del Estado recurrieron a una desesperada apelación a la conciencia humanitaria. Tomó dos formas: una tenía el carácter de pedidos de donaciones y alivio a las clases dominantes. ${ }^{72}$ La segunda fue más curiosa: súplicas cristianas contra «el agiotismo». Inspirado en la conferencia de un profesional capitalino en la Sociedad de Artesanos El Porvenir de Santa Tecla ${ }^{73}$, el mismo gobernador de La Libertad, Benjamín Arrieta Rossi, envió una carta al capellán de la Iglesia El Carmen, de Santa Tecla, Manuel Fernández:

«Hoy vengo suplicando a Ud. tenga la amabilidad de dirigir la palabra a los feligreses, a la hora de la Misa, haciendoles (sic) ver, que así como el gobierno está ayudando, así también deben proceder concienzudamente todas aquellas personas que se dedican a la venta de los cereales, quienes ante todo y más que todo por humanidad, deberán combatir en si mismos El Agiotismo (sic), que tantas veces ha sido la causa de la ruina de muchos» ${ }^{74}$.

71 Cfr. Karl Polanyi, La gran transformación los orígenes políticos y económicos de nuestro tiempo.

72 En La Libertad, el gobernador mandó una circular al respecto el 8 de julio «a varias personas pudientes de esta localidad", a la cual respondieron algunos miembros de la clase dominante, como Claudia viuda de Borbón o de las elites locales, como Jesús Hernández. AGN, Fondo Gobernación política departamental de La Libertad, serie Documentos Buenos, caja 49, Copias de correspondencia, 12 de julio de 1928. AGN, Fondo Gobernación política departamental de La Libertad, serie Documentos Buenos, caja 49, Copias de correspondencia, 20 agosto de 1928. AGN, Fondo Gobernación política departamental de La Libertad, serie Documentos Buenos, caja 49, Copias de correspondencia, 18 de julio de 1928.

73 Cri-san-temo, «Santa Tecla. Aniversario de dos sociedades. Interesantes conferencias», Diario del Salvador, 19 de julio de 1928, 2.

74 AGN, Fondo Gobernación política departamental de La Libertad, serie Documentos Buenos, caja 49, Copias de correspondencia, 4 de julio de 1928. 
Aunque desconocemos la reacción de acaparadores y comerciantes de granos, la respuesta de los grupos oligárquicos ante estas apelaciones humanitarias fue sumamente moderada; esta reacción sorprende porque en estas décadas los grupos dominantes habían demostrado una fuerte disposición a la beneficencia como mecanismo de construcción de hegemonía ${ }^{75}$. Esto aumenta la sospecha del involucramiento de algunos en el acaparamiento. $\mathrm{Y}$ en todo caso otros miembros de las clases dominantes vieron en la crisis de precios una oportunidad de negocios e intentaron introducirse en las cadenas de distribución a expensas del Estado y el maíz que distribuía. Así lo ilustraba una noticia del Diario del Salvador (31 de julio de 1928) titulada «No vende el Gobierno maíz al por mayor»:

«Siendo muchas las solicitudes que se han presentado de parte de gente pudiente y acomodada, de agricultores, empresas, etc., etc., para que se les venda maíz, por mayor, este Ministerio pone en conocimiento de los interesados que la venta del maíz pedido por el Gobierno, se hará a principal (sic) y costa a granel por medio almud y directamente al consumidor ${ }^{76}$.

Los personeros del gobierno de Romero Bosque no cedieron a tal pretensión, al constituir una medida peligrosa porque habría despertado la ira de los sectores populares urbanos y en definitiva habría minado su legitimidad en un momento dificil.

Por otro lado, los frecuentes momentos de escasez y alza de precios parecieron tener un efecto performativo sobre los sectores populares urbanos, como modelador de la fragilidad de su reproducción vital y, asimismo, de las necesarias negociaciones con el Estado para solventar el acceso a bienes y servicios básicos. Esta recurrente disposición — tal vez por su recurrencia

75 Ello se puede ver en la relación de los Guirola con El Porvenir. Luis Rubén González Márquez, «Sociabilidad y organizaciones artesanales-obreras. La Sociedad de Artesanos El Porvenir de Santa Tecla, 1902-1932».

76 Estas pretensiones de sacar provecho de la crisis contradecían el discurso de reciprocidad social de la beneficencia y de las relaciones de patronazgo, con lo cual se minaba el potencial hegemónico oligárquico. Anónimo, «No vende el gobierno maíz al por mayor», en Diario del Salvador, 31 de mayo de 1928, 1. 
desde el siglo XIX se encontraba fuertemente internalizada - era central en configurar la subjetividad de estos sectores cuando se activaban políticamente mediante la acción colectiva en la esfera pública, como «muchedumbre citadina ${ }^{77}$, sin convertirse en motivación principal durante estos episodios. Sorprendentemente, las alzas de 1927-1929 no se convirtieron en motivo directo de las campañas de protesta de la muchedumbre urbana durante la ola de movilización de 1927-1932, las cuales se orientaban hacia las mejoras salariales, a otros servicios públicos como la electricidad o el transporte, la apertura del sistema político o, incluso, a cuestionar el poder oligárquico ${ }^{78}$.

En otras palabras, como se veía en los momentos de encarecimiento, la política contenciosa alimentaria ${ }^{79}$ en El Salvador, sustentada en la tradición del motín de subsistencias y que fue tan fértil en las grandes movilizaciones y revoluciones de la Europa central y oriental coetánea, tuvo menores alcances que en estos casos, aunque fue constitutiva de las orientaciones políticas cotidianas de los grupos populares urbanos. Las noticias de esos años describen una disposición a la resistencia cotidiana, el bandidaje, la concentración masiva en la esfera pública y la acción directa por la fuerza entre los sectores urbanos populares alrededor de la recepción del maíz barato del Estado. La disposición de resistencia y acción se aproximaba al tipo ideal del motín de subsistencia, sin llegar nunca a él. El Diario del Salvador reportaba, en agosto de 1928, que un sujeto fue arrestado por «hurto de dinero y tiquetes de la venta de maíz en la Administración de rentas» ${ }^{80}$; por otro lado, el 28 de julio, se registraron "dos accidentes en un expendio de maíz», en los cuales una mujer sufrió un síncope y la otra se fracturó el brazo, «en la lucha por comprar maíz».Y cerraba la nota: «Estos casos se repiten con frecuencia debido a la aglomeración de la gente» ${ }^{81}$.

77 Eric Hobsbawm, Rebeldes primitivos. Estudio sobre las formas arcaicas de los movimientos sociales en los siglos XIX y XX (Barcelona: Ariel, 1983), 165-91.

78 Luis Rubén González Márquez, «Política popular contenciosa: movilización social y hegemonía en El Salvador, 1919-1932», 122-133.

79 Lynne Taylor, «Food Riots Revisited».

80 Anónimo, "robo en una de las ventas de maíz del gobierno", en Diario del Salvador, 2 de agosto de 1928, 3 .

81 Anónimo, «Dos accidentes en un expendio de maíz», en Diario del Salvador, 28 de julio de 1928,1 . 
Más aún, en otro caso del 13 de julio de 1928 relataba cómo una anciana "que trataba de comprar maíz, estuvo a punto de morir por asfixia», se profundiza en algunos aspectos de estas aglomeraciones como su dirección hacia el Estado, la competencia por la sobrevivencia y el proceso de conversión de estos heterogéneos sectores en un nuevo actor, la muchedumbre citadina: «La señora penetró entre el compacto grupo de compradoras que forcejeaban por ser las primeras en ser atendidas dando el aspecto de una tumultuosa ola humana: unas proferían gritos de cólera y otras ayes (sic) de dolor». ${ }^{82}$ Un aspecto adicional deja entrevar está y será palpable en otras expresiones de la acción de la muchedumbre citadina es el protagonismo de las mujeres, indicio tanto de la desigual división del trabajo reproductivo entre las familias urbanas como el potencial de conversión de la responsabilidad de suplir los alimentos y afrontar la sobrevivencia cotidiana en liderazgo femenino de base.

\section{Conclusión: ¿Una época de esplendor?}

Desde su mismo título - aunque también en su contenido- el libro de Gustavo Herodier, San Salvador: el esplendor de la ciudad, con sus cuidadas fotografias de la arquitectura y la vida en la ciudad entre 1880 y 1930, indica una narrativa nostálgica hacia el pasado. El libro se encuentra permeado por una sensación de añoranza por las décadas de remozamiento de la ciudad al calor del crecimiento cafetalero que es compartida en la opinión y crítica cultural de determinados círculos de la opinión pública actual ${ }^{83}$. Siguiendo a Walter Benjamín, desde los fragmentos sobre condiciones de reproducción material de los sectores populares urbanos, es posible cuestionar esa narrativa y encontrar la barbarie en esos documentos de cultura, la imagen del pasado que «relumbra en un instante de peligro» ${ }^{84}$.

82 Anónimo, «Lucha desesperada entre las compradoras de maíz», en Diario del Salvador, 13 de julio de $1928,1$.

83 Gustavo Herodier, San Salvador, el esplendor de una ciudad: 1880-1930 (San Salvador: ASESUISA-Fundación María Escalón de Núñez, 1997).

84 Walter Benjamín, «Sobre el concepto de historia», en Tesis sobre la historia y otros fragmentos (México: Clío, 2005), 19-25. 
En efecto, la misma economía cafetalera que produjo esos edificios y diversiones públicas de la supuestamente época dorada de San Salvador estaba signada por un desequilibrio que precarizaba a la mayor parte de habitantes de la ciudad (mismos que están ausentes de las fotografias) y del resto de núcleos urbanos del país. La marginación de la agricultura de subsistencias, la difusión de un mercado alimentario y la tendencia a la continuidad de los salarios en el período de entreguerras, a pesar de un leve descenso en el largo plazo, producían una inestabilidad lesiva. En su momento, se le denominó el problema de las subsistencias a la incertidumbre en el aprovisionamiento de bienes básicos de los trabajadores urbanos, la cual se agravaba por la epidemia de alcoholismo y por las desigualdades de género y generacionales.

En sus momentos más agudos, por la vía del encarecimiento de subsistencias, por escasez de granos o acaparamiento, tensó las relaciones de estos grupos citadinos, el Estado y las clases dominantes. Estas condiciones de precarización y la marginalidad derivada, junto a estos episodios de hambre y empobrecimiento, modelaron a los sectores populares urbanos en sus relaciones de oposición y negociación con otros colectivos, así como en su producción discursiva cotidiana. Si bien debieron pasar por otras mediaciones organizativas y político discursivas, la precariedad dispuso a los sectores populares urbanos hacia la negociación y resistencia por la sobrevivencia como muchedumbre citadina; los dispuso, en suma, hacia la construcción de una política popular que se orientó a presionar de múltiples maneras al Estado hacia el rompimiento con el liberalismo económico. 


\section{REFERENCIAS BIBLIOGRÁFICAS}

\section{Fuentes primarias}

Archivo General de la Nación

Fondo de la Gobernación Política Departamental de La Libertad, Documentos buenos,

1902-1933

Fondo de la Gobernación Política Departamental de La Libertad, Libros, 1902-1933

Biblioteca especializada, Anuarios estadísticos, 1928-1944

Archivo Municipal de Santa Tecla

Libros de Actas, 1902-1932

Biblioteca «Florentino Idoate», Universidad Centroamericana «José Simeón Cañas»

Anuarios estadísticos, 1916-1919

Biblioteca Nacional de El Salvador «Francisco Gavidia»

Diario del Salvador, 1901-1933

Memorias del Ministerio de Gobernación, Agricultura y Fomento, 19071933

Memorias de Hacienda, Crédito público, Industria y Comercio, 1927

Archivo del Diario Oficial en la Imprenta Nacional

Diario Oficial, 1912-1940 http://imprentanacional.gob.sv/archivo-digitaldel-diario-oficial/ 


\section{Fuentes secundarias}

Acosta Rodríguez, Antonio. Los orígenes de la burguesía de El Salvador: el control sobre el café y el Estado, 1848-1890. San Salvador-Sevilla:TEIAA-IEALUFG Editores, 2014.

Acuña Ortega,Víctor Hugo. "The Formation of the Urban Middle Sectors in El Salvador, 1911-1944». En Landscape of Struggle: Politics, Society and Community in El Salvador, editado por Leigh Binford, y Aldo LauriaSantiago, 39-49. Pittsburgh: University of Pittsburgh Press, 2004.

Aldcroft, Derek. «Las consecuencias económicas de la guerra y de la paz, 1919-1929». En Europa en crisis, 1919-1939, editado por Mercedes Cabrera, Santos Juliá, y Pablo Martín Aceña, 1-24. Madrid: Editorial Pablo Iglesias, 1991.

Alvarenga, Patricia. Cultura y ética de la violencia: El Salvador, 1880-1932. San José: EDUCA, 1996.

Barrios Escobar, Lina Eugenia. Tras las huellas del poder local: la Alcaldía Indígena en Guatemala, del siglo XVI al siglo XX. Guatemala: Universidad Rafael Landívar-Instituto de Investigaciones Económicas y Sociales, 2001.

Benjamin, Walter. "Sobre el concepto de historia». En Tesis sobre la historia y otros fragmentos, 17-31. México: Clío, 2005.

Braudel, Fernand. Civilización material, economía y capitalismo. Siglos XV-XVIII. Tomo I: las estructuras de lo cotidiano: lo posible y lo imposible. Madrid:Alianza, 1984.

Browning, David. El Salvador: la tierra y el hombre. 2ed ed. San Salvador: Dirección de Publicaciones e Impresos, 1982.

Bulmer-Thomas, Víctor. La economía política de Centroamérica desde 1920. San José: Banco Centroamericano de Integración económica-EDUCA, 1989.

Campos Lara, Óscar. «Cafetaleros de Santiago de María : la formación de un poder microregional en la Sierra Tecapa de Usulután, 1874-1917». Tesis de licenciatura, Universidad Tecnológica de El Salvador, 2007.

Castro, Alirio Augusto. «Datos para la economía social salvadoreña». Tesis doctoral en jurisprudencia y ciencias sociales, Universidad de El Salvador, 1922. 
Ching, Erik. «Prólogo: Una República agraria y la historia de la tierra en El Salvador de la Post-independencia». En Una República agraria: los campesinos en la economía y la política de El Salvador en el siglo XIX, de Aldo Lauria-Santiago, 9-27. San Salvador: Dirección de Publicaciones e Impresos, 2003. . «From clientelism to militarism:The state, politics and authoritarianism in El Salvador, 1840-1940». Tesis doctoral, Universidad de California en Santa Barbara, 1997.

Durham, William. Escasez y sobrevivencia en Centroamérica : orígenes ecológicos de la guerra del fútbol. San Salvador El Salvador: UCA Editores, 1988.

Fonseca, Pedro. Demografía salvadoreña. San Salvador: Imprenta Rafael Reyes, s.f.

Foucault, Michel. Defender la sociedad: curso en el Collège de France (19751976). Buenos Aires: Fondo de Cultura Económica, 2000.

Frye, David. «Metrología». University of Michigan. David Frye. Writer... Translator, 9 de febrero de 2012, disponible en: http://www-personal.umich. edu/ dfrye/fanega.htm.

González Márquez, Luis Rubén. «Política popular contenciosa: movilización social y hegemonía en El Salvador, 1919-1932». Tesis de maestría en Sociología, Facultad Latinoamericana de Ciencias Sociales, Sede Ecuador, 2017.

_- «Sociabilidad y organizaciones artesanales-obreras. La Sociedad de Artesanos El Porvenir de Santa Tecla, 1902-1932». Tesis de licenciatura en Historia, Universidad de El Salvador, 2012.

Gould, Jeffrey, y Aldo Lauria Santiago. «Nos llaman ladrones y se roban nuestro salario: hacia una reinterpretación de la movilización rural salvadoreña, 1929-1931». Revista de historia nº 51-52 (diciembre de 2005):287355.

1932: rebelión en la oscuridad. San Salvador: Ediciones Museo de la Palabra y la Imagen, 2008.

Herodier, Gustavo. San Salvador, el esplendor de una ciudad: 1880-1930. San Salvador: ASESUISA-Fundación María Escalón de Núñez, 1997.

Hobsbawm, Eric. Historia del siglo XX: 1914-1991. Barcelona: Crítica, 1995. Rebeldes primitivos. Estudio sobre las formas arcaicas de los movimientos sociales en los siglos XIX y XX. Barcelona: Ariel, 1983. 
Isunza Vera, Ernesto. «Cosmovisión de la vieja guardia. Organizaciones y cultura comunistas centroamericanas, 1922-1934». Tesis de licenciatura, Universidad Veracruzana, 1993.

Lauria-Santiago, Aldo. Una República agraria: los campesinos en la economía y la politica de El Salvador en el siglo XIX. San Salvador: Dirección de Publicaciones e Impresos, 2003.

Lindo-Fuentes, Héctor. La economía de El Salvador en el siglo XIX. San Salvador: Dirección de Publicaciones e Impresos, 2002.

__. «La United Fruit Company y el empréstito de 1922 en El Salvador». Boletín AFEHC n64 (4 de marzo de 2015), disponible en: http:// afehc-historiacentroamericana. org/index.php?action=fi_aff\&id $=393$.

López Bernal, Carlos Gregorio. «Poder central y poder local en la construcción del Estado en El Salvador, 1840-1890». Tesis doctoral, Universidad de Costa Rica, 2007.

- Tradiciones inventadas y discursos nacionalistas: El imaginario nacional de la época liberal en El Salvador, 1876-1932. San Salvador: Editorial Universitaria, 2007.

Loucel Lucha, Carlos. «Crisis, aguardiente y café (1898-1930)». En Los estancos, las prácticas monopólicas y las rentas del Estado en El Salvador, editado por Pedro Escalante Arce y Eugenia López Velásquez, 227-270. San Salvador: Dirección de Publicaciones e Impresos Consejo Nacional para la Cultura y el Arte, 2008.

Masferrer, Alberto. El minimum vital y otras obras de carácter sociológico. Guatemala: Ediciones del gobierno de Guatemala, 1951.

- ¿Qué debemos saber? Cartas a un obrero. San Salvador: Dirección General de Cultura del Ministerio de Educación, 1968.

McCreery, David. «Debt Servitude in Rural Guatemala, 1876-1936». Hispanic American Historical Review Vol. 63, nº 4 (1984): 735-759.

Mejía Pérez, José. «Censo del $1^{\circ}$ de mayo de 1930». San Salvador: Dirección General de Estadística, 1939.

Menjívar, Rafael. Acumulación originaria y desarrollo del capitalismo en El Salvador. San Salvador: Abril Uno, 2005.

Montes, Segundo. El Salvador 1988: estructura de clases y comportamiento de las fuerzas sociales. San Salvador: IDHUCA, 1988. 
Morales, Herberth. «Dinámicas poblacionales de Santa Tecla: población en Santa Tecla, 1854-1882 (inédito)». s.e., s.f.

—. «Historia local de Jayaque». Tesis de licenciatura, Universidad de El Salvador, 2013.

Polanyi, Karl. La gran transformación los orígenes políticos y económicos de nuestro tiempo. México: Fondo de Cultura Económica, 2003.

Portillo, Geraldina. La tenencia de la tierra en El Salvador: La Libertad, 18971901, Santa Ana, 1882-1884, 1897-1898. San Salvador: Instituto de Estudios Históricos, Arqueológicos y Antropológicos de la Universidad de El Salvador, 2006.

Reyes, Rafael. Apuntamientos estadísticos sobre la República de El Salvador de 1888. San Salvador: Imprenta Nacional, 1888.

Romero, Luis Alberto. «Los sectores populares urbanos como sujetos históricos». Última década $\mathrm{n}^{\circ} 7$ (agosto de 1997): 9-31.

Sevillano Payés, Dennis. «La política rural de mejoramiento social del General Maximiliano Hernández Martínez y sus contradicciones, 19321944». Revista de Museología Kóot Año 4, no 5 (2014): 9-22.

Suárez, Belarmino. Pláticas populares. Lo que no debe ignorar el salvadoreño acerca de la economía nacional. San Salvador: Banco Agrícola Comercial, 1973.

Taylor, Lynne. «Food Riots Revisited». Journal of Social History Vol. 30, n 2 (Invierno de 1996): 483-496.

Thompson, Edward Palmer. «La economía moral de la multitud en la Inglaterra del siglo XVIII». En Tradición, revuelta y conciencia de clase, 62-134. Barcelona: Crítica, 1984.

Tilly, Charles. «Capítulo 6: Rusia y sus vecinos». En Las revoluciones europeas, 1492-1992,232-284. Barcelona: Crítica, 2000.

Universidad Libre de Berlín. «1914-1918-online: International Encyclopedia of the First World War». Enciclopedia en línea, 28 de mayo de 2011, disponible en: http://www.1914-1918-online.net/.

Wilson, Evertt Alan. La crisis de la integración nacional en El Salvador: 19191935. San Salvador: Dirección de Publicaciones e Impresos, 2004. 